\title{
Photosynthetic Responses of Eelgrass (Zostera marina L) to Light and Sediment Sulfide in a Shallow Barrier Island Lagoon
}

Jill Lynn Goodman

College of William and Mary - Virginia Institute of Marine Science

Follow this and additional works at: https://scholarworks.wm.edu/etd

Part of the Plant Sciences Commons

\section{Recommended Citation}

Goodman, Jill Lynn, "Photosynthetic Responses of Eelgrass (Zostera marina L) to Light and Sediment Sulfide in a Shallow Barrier Island Lagoon" (1992). Dissertations, Theses, and Masters Projects. Paper 1539617651.

https://dx.doi.org/doi:10.25773/v5-pdzq-8765

This Thesis is brought to you for free and open access by the Theses, Dissertations, \& Master Projects at W\&M ScholarWorks. It has been accepted for inclusion in Dissertations, Theses, and Masters Projects by an authorized administrator of W\&M ScholarWorks. For more information, please contact scholarworks@wm.edu. 


\title{
PHOTOSYNTHETIC RESPONSES OF EELGRASS \\ (Zostera marina L.) TO LIGHT AND SEDIMENT SULFIDE IN A SHALLOW BARRIER ISLAND LAGOON
}

\begin{abstract}
A Thesis
Presented to

The Faculty of the School of Marine Science

The College of William and Mary in Virginia
\end{abstract}

In Partial Fulfillment

of the Requirements for the Degree of

Masters of Art

By

Jill L. Goodman

1992

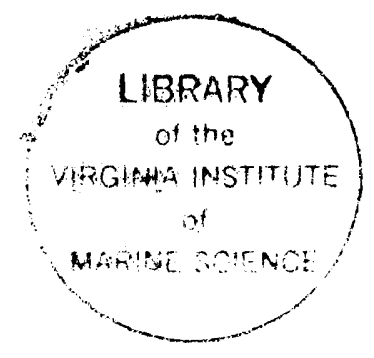


APPROVAL SHEET

This thesis is submitted in partial fulfillment of the requirements for the degree of

Master of Arts

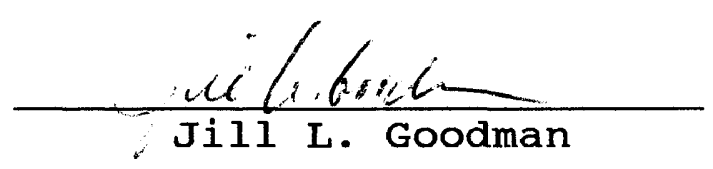

Approved, August 1992

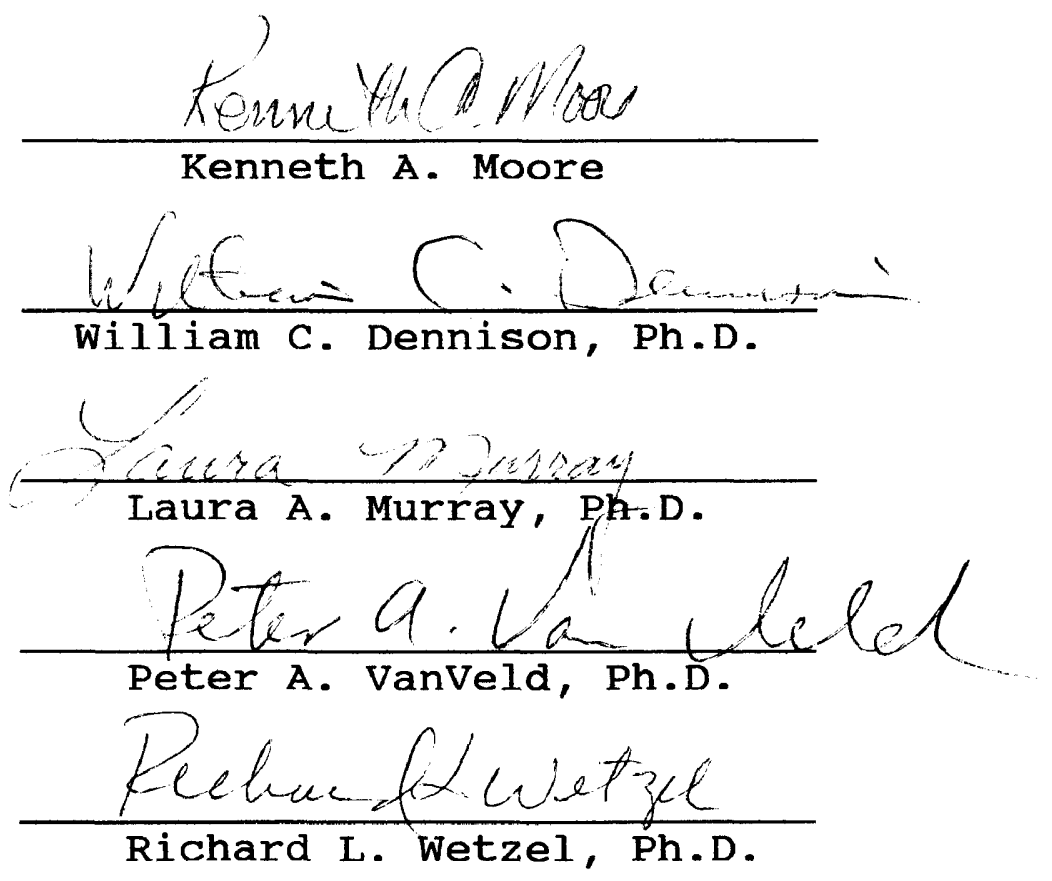




\section{TABLE OF CONTENTS}

Ackowledgements ........................ iv

List of Tables ......................... v

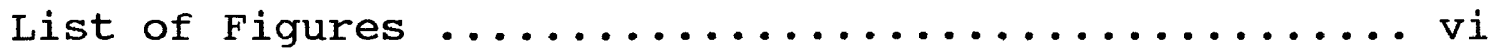

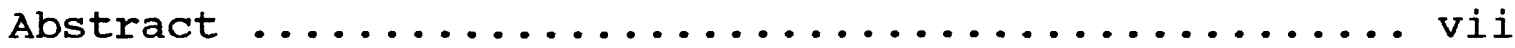

I. Introduction $\ldots \ldots \ldots \ldots \ldots \ldots \ldots \ldots \ldots \ldots \ldots \ldots \ldots \ldots \ldots \ldots$

II. Methods ......................... 8

III. Results ......................... 20

IV. Discussion $\ldots \ldots \ldots \ldots \ldots \ldots \ldots \ldots \ldots \ldots \ldots \ldots \ldots$

V. Conclusions .......................... 42

Appendix A .......................... Al

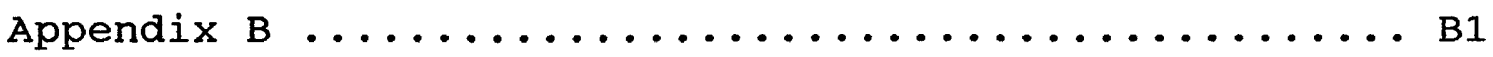

References .............................. 44

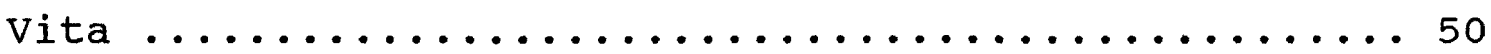




\section{ACKNOWLEDGEMENTS}

I would like to thank my major advisor, Mr. Ken Moore for all his time patience and encouragement throughout this research. Thanks to Dr. Bill Dennison for his expertise in preparing the experimental design for this project. A special thanks to Dr. Laura Murray for her encouragement and insight all these years. Drs. Dick Wetzel and Peter Vanveld are thanked for their review and direction in preparing this manuscript.

I would also like to thank Art Schwarzschild and Chris Buzzelli for helpful input. Thanks to Cindi Horton for her help in data analysis and general encouragement. A big thanks to Lori Morris for her computer knowledge, help in the field, oatmeal cookies, and for keeping me sane.

This work is dedicated to my mother who, throughout my life, has encouraged and inspired me to succeed in whatever I do. 


\section{LIST OF TABLES}

Table 1: ANOVA (p-values-Field) $\ldots \ldots \ldots \ldots \ldots \ldots$

Table 2: ANOVA (p-values-Microcosm) $\ldots \ldots \ldots \ldots \ldots \ldots . . .24$

Table $3: \mathrm{H}_{\text {sat }}$ and $\mathrm{H}_{\text {comp }}$ Comparison $\ldots \ldots \ldots \ldots \ldots$ 


\section{LIST OF FIGURES}

Figure 1: Map of Chincoteague Bay ............. 9

Figure 2: Experimental Design (Field) ........... 10

Figure 3: Experimental Design (Microcosm) ........ 12

Figure 4: Mean PI Curves (Microcosm) ............ 21

Figure 5: Mean PI Curves (Field) .............. 22

Figure 6: P-max and Initial slope (Field) ........ 27

Figure 7: P-max and Respiration (Microcosm) ....... 28

Figure 8: Initial slope (Microcosm) ............ 29

Figure 9: $I_{c}$ and $I_{k}($ Microcosm) $\ldots \ldots \ldots \ldots \ldots \ldots$

Figure 10: Chlorophyll (Field) ............... 31

Figure 11: Chlorophyll (Microcosm) ............ 32

Figure 12: $\mathrm{H}_{\mathrm{comp}}$ (Field and Microcosm) .......... 35 


\section{ABSTRACT}

Highly reducing sediments are prevalent where seagrasses exist. Under such anoxic sediment conditions, hydrogen sulfide accumulates as an end product of anaerobic respiration. Hydrogen sulfide can be toxic to marine macrophytes and in combination with other factors may result in severe stress and eventual loss of seagrass populations. The photosynthetic response of Zostera marina L. (eelgrass) to manipulations in sediment sulfide concentration and light regimes were examined in Chincoteague Bay in June of 1991. In both field and microcosm experiments screens were used to decrease downwelling irradiance by $80 \%$ and sediment sulfide levels were enriched using $\mathrm{NaS}_{2}$ in a replicated factorial design. Photosynthesis vs. irradiance relations and leaf chlorophyll content were determined at the end of three weeks. There was no photosynthetic response of the eelgrass to decreases in light over a 21 day period. This may be due to the ability of the eelgrass in Chincoteague Bay to adapt daily to variable light. It seems there were adequate hours of light, even in the low light treatments to allow these plants to photosynthesize at normal levels. The P-max was reduced in eelgrass leaf tissue exposed to treatments of sediment sulfide above 500uM. The respiratory demand of the eelgrass is increased with sediment sulfide levels above 500uM. This implies that the maintenance cost (ie. respiratory demand) is increased as more $\mathrm{O}_{2}$ is transported from shoots to the root rhizosphere. Total chlorophyll is also increased with sulfide concentrations above 500uM. This increase along with the decrease seen in the initial slope, implies a decrease in efficiency of light harvesting as sediment sulfide is increased. 


\section{INTRODUCTION}

Seagrasses are a group of approximately 50 species ( 12 genera) of angiosperms growing completely submersed in saline environments (den Hartog 1970). These macrophytes flourish in embayments and other sheltered coastal areas of polar, temperate, and tropical regions of the world (Mukai et al. 1979). Despite environmental conditions which include marked fluctuations in light availability, temperature, and salinity, seagrasses are among the most productive systems in the world (McRoy \& McMillan 1977, Zieman \& Wetzel 1980). On a per area basis, seagrasses are more productive than cultivated corn or hay (Thayer et al. 1975). Besides providing a major source of primary production, seagrasses serve many other functions in marine systems. They are an important component in bottom stabilization and retarding of currents (Boudouresque \& de Grissae 1983, Ward et al. 1984, Fonseca et al. 1982). They provide nursery grounds for fish and invertebrates and a substrate for epiphytes (Kikuchi \& Peres 1977, Bulthius \& Woelkerling 1983, Borum 1985). Seagrasses are also the primary producers of detrital based food chains (Wood et al. 1969).

Zostera marina L. (eelgrass) is a temperate seagrass that grows in highly reducing sandy and muddy sediments of 
coastal bays and estuaries in the Northern Hemisphere (Smith et al. 1988, Thayer et al. 1975). Eelgrass can tolerate a broad range of salinities from $10-40$ ppt, and water temperatures from $0-40^{\circ} \mathrm{C}$ (Thayer et al. 1975). However, optimum growth and reproduction of $z$.marina is exhibited at salinities of $10-20$ ppt and temperatures between $10-20^{\circ} \mathrm{C}$ (Biebl \& McRoy 1971).

Photosynthesis begins with the absorption of light by light harvesting chlorophyll $a$ and $b$ protein complexes (Salisbury \& Ross 1985). Light varies from one habitat to another and may also show seasonal variation within a habitat. Adaptation of marine autotrophs to light has been demonstrated mainly in studies on phytoplankton and macroalgae, but is also found among vascular plants. For example, shade adapted plants maximize their photosynthetic rate at lower light intensities than sun adapted plants. Seagrasses accustomed to higher light regimes have more leaf surface area and less total chlorophyll (Drew 1978, Wiginton \& McMillan 1979) .

The euphotic zone of phytoplankton is generally taken to be $1 \%$ of surface irradiance (Strickland 1958). Eelgrass typically exhibit a depth limitation at 10-25\% of surface irradiance (Dennison 1987). The difference between the light requirements of eelgrass and phytoplankton is likely due to the greater respiratory demands of the macrophytes. Seagrasses have extensive below ground respiratory tissue as 
well as large respiratory demands for tissues used for both structure and translocation (Dennison 1987). Phytoplankton with their more simplified structure do not have this extensive respiratory demand, and therefore require less light to survive.

Studies suggest depth limits of submersed macrophytes is controlled by light availability. Studies by Chambers \& Kalff (1985) and Chambers \& Prepas (1988) show that the maximum depth at which freshwater macrophytes are found is positively correlated with underwater light penetration in lakes. Kelly, et al. (1983), also demonstrated the constant relationship between primary productivity and light in macrophyte dominated freshwater rivers.

Light availability is also the primary factor that affects the structure of seagrass meadows (Dennison \& Alberte 1982, Dawes \& Tomasko 1988). Seagrasses are typically found in coastal areas where depths increase with distance from the shore. In these areas light intensity gradients are formed by the attenuation of light in the water column and by the plant canopy itself (Mazella \& Alberte 1986). For example, Thalassia testudinum, a tropical species of seagrass, typically exhibits differences in shoot density, leaf area, and chlorophyll content among shallow and deep areas (Dawes \& Tomasko 1988). In Chesapeake Bay, the distribution of the seagrasses $z$. marina and Ruppia maritima is related to light requirements with $R$. maritima found in 
shallow, higher light areas and $Z$. marina dominating in low light, deeper areas (Wetzel \& Penhale 1983). Z. marina also possesses the ability to alter its total chlorophyll, ratio of chlorophyll a/b, and shape of leaves in direct response to light availability (Dennison \& Alberte 1982, Goldsboro \& Kemp 1988). Myriophyllum brasiliense, a freshwater submerged plant, has been found to demonstrate a major difference in light dependency between aerial and submersed leaves, such that saturation levels were much lower in the shade adapted submersed leaves than in the sun adapted aerial leaves (Libes 1986). Reports of declines in seagrasses due to increases in water turbidity also provide evidence that light is the major factor determining the distribution of seagrasses (Orth \& Moore 1983). While it is true that most seagrasses have adapted to low light habitats of coastal environments, light availability is often the primary limiting factor for seagrass growth (Dennison \& Alberte 1985, Dennison 1987). Wetland sediments, where anaerobic metabolism and sulfate reduction dominate, have been the focus in studies on the effect of accumulation of $\mathrm{H}_{2} \mathrm{~S}$ on plant responses. Seagrasses are also found in organic rich, highly reducing sediments. Shoot lacunal development and rates of photosynthesis are critical to the downward transport of $\mathrm{O}_{2}$ from the leaves to the roots of seagrasses (Pulich 1989). When photosynthetic activity is low, roots must tolerate significant periods of anoxia and/or hypoxia (Smith et al. 
1984, Smith et al. 1988, Zimmerman et al. 1989).

When the $\mathrm{O}_{2}$ supply in the sediments becomes limiting, aerobic respiration is replaced by anaerobic metabolic processes (Koch et al. 1990). During these periods of anoxia, heterotrophic anaerobic bacteria use inorganic ions as terminal electron acceptors to break down organic matter (Hines et al. 1989). Where adequate supplies of sulfate and organic matter are present, sulfide is produced in these anaerobic sediments by sulfate reducing bacteria of the genus Desulfovibrio (Ingold \& Havill 1984). These organisms use sulfate as their terminal electron acceptor for oxidative phosphorylation, the amount of hydrogen sulfide $\left(\mathrm{H}_{2} \mathrm{~S}\right)$ present in marine sediments being dependent on this process (Ingold \& Havill 1984, Howarth \& Giblin 1983).

In salt marsh sediments, where spartina alterniflora is found, $\mathrm{H}_{2} \mathrm{~S}$ has been found to be the primary factor inhibiting plant growth and increasing mortality. The mechanisms for this apparent inhibition are not understood (Delaune et al. 1984, King et al. 1982). Several possibilities exist. For example, there is a reduction in ATP generation due to the switch from aerobic to anaerobic metabolic processes (Koch \& Mendelssohn 1989). In addition, sulfide accumulation has been found to decrease the activity of root metallo-enzymes, such as important oxidases, used in the electron transport system of respiration (Koch et al. 1990). $\mathrm{H}_{2} \mathrm{~S}$ may also affect alternate anoxic pathways by limiting the production 
of ADH (alcohol dehydrogenase), which is the enzyme catalyzing the terminal step in alcoholic fermentation (Koch et al. 1990). Ethanol, the end product of alcoholic fermentation, when released to the sediment may be a major carbon drain from the plant (Hines et al. 1989). In order to eliminate this carbon drain, fermentative metabolism is maintained only at low levels (Smith et al. 1988). The reduction in nitrogen uptake caused by increases levels of sulfide in sediments surrounding $S$. alterniflora may also be detrimental to its growth and production.

Rice, which is also found in highly reduced, water saturated soils, has been found to be limited in growth, root hair development, and nutrient uptake by increased levels of sediment sulfide (Joshi \& Hollis 1977). Chlorosis and stunted growth are indications that rice plants are being stressed by highly reduced soil conditions (Koch \& Menselssohn 1989).

The growth of Salicornia europea, which is also associated with sulfide containing wetland sediments, has been found to be unaffected by increases in sediment sulfide (Wilkin-Michalska 1985). Sulfide pretreatment inhibited activity of two metallo-enzymes in plants from the upper marsh, such as spartina foliosa and Scirpus robustus, but had no effect on enzymes from $S$. europea (Cooper 1984). Aster tripolum, a wide ranging halophyte, also appeared to be tolerant of sulfide at concentrations frequently encountered 
in salt marshes (Cooper 1984).

The studies cited here have examined the effect of sulfide on growth and biomass of several wetland species. However, no studies have addressed the interactive effect of increases in sediment $\mathrm{H}_{2} \mathrm{~S}$ and decreases in available light on wetland plants. With reduction in light, seagrasses experience reductions in the rate of photosynthesis. Decreased rates of photosynthesis lead to decreases in $\mathrm{O}_{2}$ production and therefore the availability of $\mathrm{O}_{2}$ to aerate the sediment is also reduced. With low levels of $\mathrm{O}_{2}$ in the sediments, the accumulation of $\mathrm{H}_{2} \mathrm{~S}$ is enhanced. This increase in sediment sulfide may lead to a reduction in the photosynthetic rate of the plant.

The objectives of this study were to determine the interactive effects of increased levels of sediment sulfide coupled with the reduction of light on the rates of photosynthesis and respiration and response of total chlorophyll and chlorophyll a/b ratios in $\boldsymbol{Z}$. marina in Chincoteague Bay, a shallow coastal lagoon. These objectives were examined both in a field experiment and in controlled microcosm experiment. 


\section{METHODS}

Chincoteague Bay, a shallow coastal lagoon located along Maryland and Virginia's eastern shore was chosen as the study site for this research (Figure 1). Chincoteague Bay is protected from the Atlantic Ocean by Assateague Island on its eastern side. Inlets are found at the north and south end of the bay with an exchange rate of $7 \%$ bay volume/day (orth et al. 1987) The mean water depth is only $1.1 \mathrm{~m}$ and the tidal range is approximately 0.3m (Orth et al. 1990). Z. marina is found along the eastern portion of Chincoteague Bay.

An eelgrass bed in Chincoteague Bay approximately one mile due east from Greenbackville, VA was chosen as the field site for this research in June of 1991. Cores of $Z$. marina were removed from an area of dense, homogeneous cover and used in the laboratory experiment conducted on the pier at the Greenbackville field station.

The field study consisted of five different sulfide/light treatments (Figure 2). Intact cores were removed temporarily from the site. An agar plate containing a concentration of sulfide was placed in the cored hole. The intact core was then replaced in the hole above the agar plate. The treatments were as follows: control, high light/high sulfide, high light/low sulfide, low light/high 
Figure 1: Map of Chincoteague Bay, located along the eastern shores of Maryland and Virginia. The field site for this study is indicated by the black arrow in the eastern portion of the lower bay. 


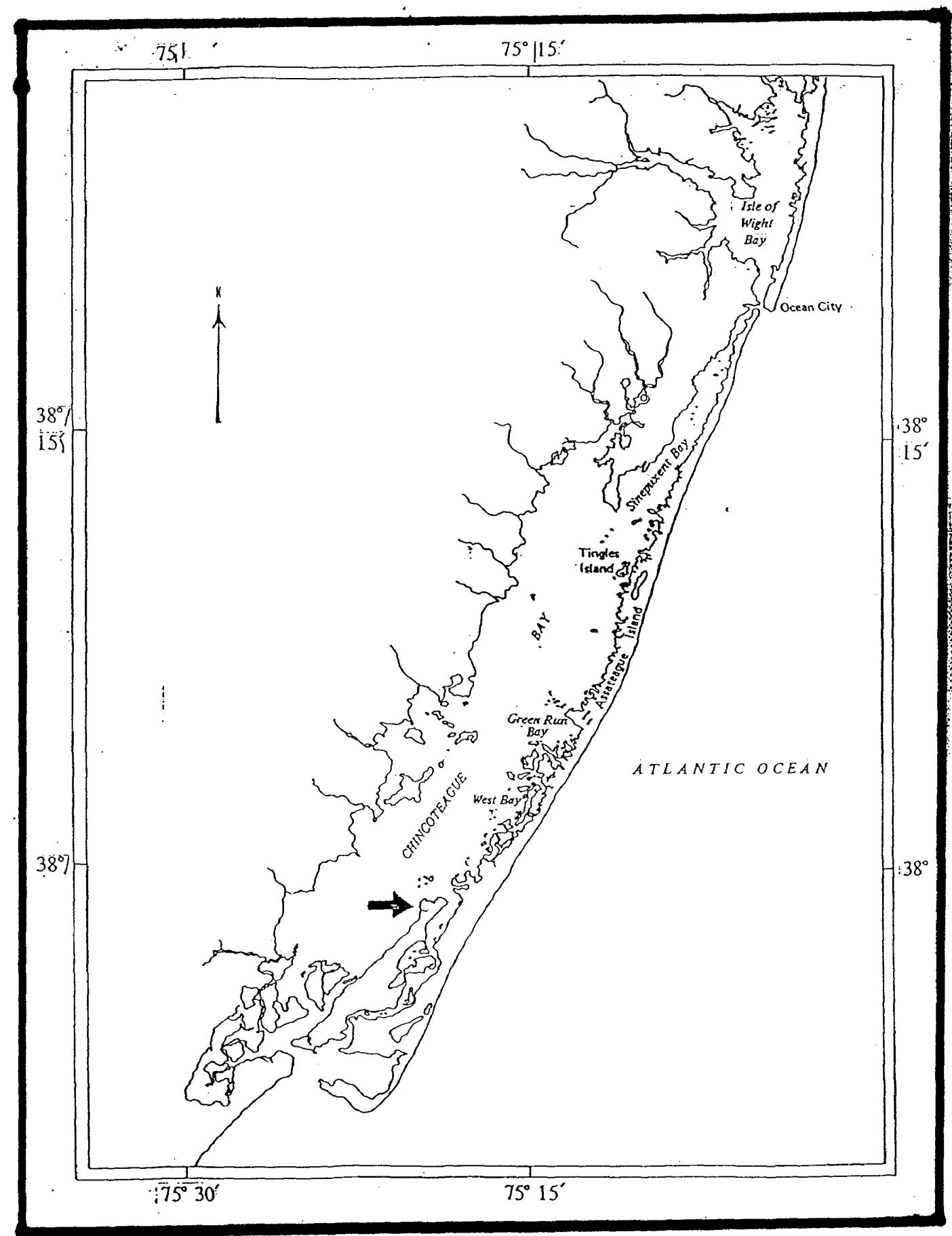


Figure 2: Schematic of the experimental design used in the field experiment. Low light was achieved through the use of shade cloths that reduced surface irradiance by $80 \%$ High light was ambient irradiance. High sulfide (HS) cores had amounts of sodium sulfide added to agar plates to achieve a maximum concentration of 500uM. Low sulfide (LS) cores had no additions to the agar. The control (C) plot was unmanipulated. This station set-up was replicated 5 times. 


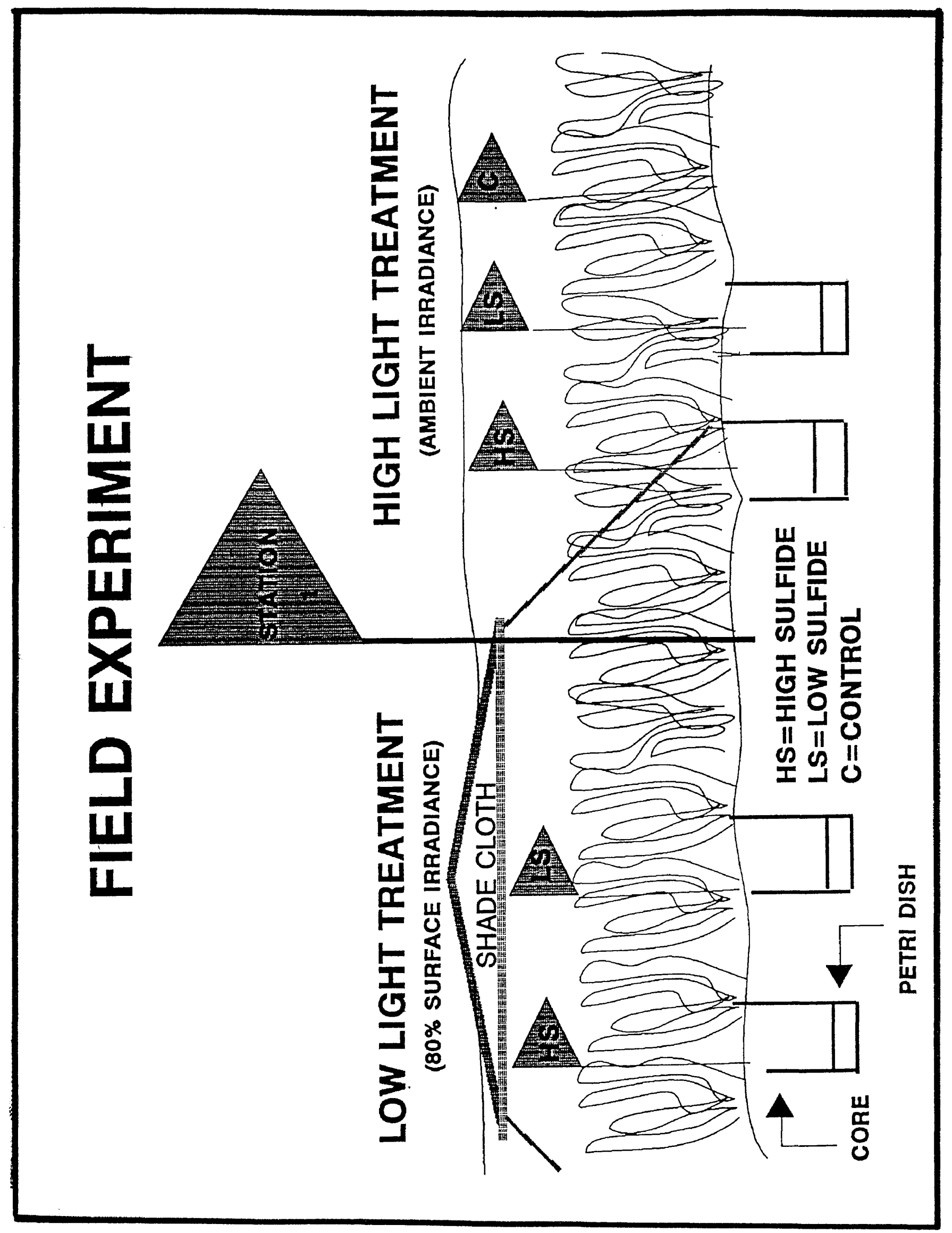


sulfide, and low light/low sulfide. The control was unmanipulated, no coring, no light changes, and no sulfide additions. The high light/low sulfide treatment was considered the manipulative control in that it was subjected to the stress of coring and received ambient light and sulfide. High sulfide treatments had concentrations ( $5 \mathrm{mM} \mathrm{Na}$ $x 9 \mathrm{H}_{2} \mathrm{O}$ ) of sodium sulfide dissolved in the agar plates to create a maximum sulfide concentration of 500uM. Low sulfide treatments represent ambient sediment sulfide and therefore have no additions of sodium sulfide to the agar. Pore water was sampled from the cores using "sippers" which were inserted in the center of the cores. These sippers were made of $1.2 \mathrm{~cm}$ diameter PVC pipe, tygon tubing, and 5uM mesh. The pore water was analyzed spectrophotometrically to determine actual sulfide concentrations. The design allowed pore water from a depth of $5-15 \mathrm{~cm}$ with in the core to be extracted. There were five replicates of each of the treatments in the field. Net apparent photosynthesis was measured at the beginning of June $1991\left(T_{0}\right)$ and after 21 days.

Twenty four cores were taken from the field site and placed in tanks connected to flowing sea water on the pier at the Greenbackville field station (Figure 3). Cores remained separate and intact throughout the experiment. Agar plates and shade cloths were placed below and above the cores respectively in an attempt to create different sulfide/light treatments. 
Figure 3: Diagram of the microcosm experimental design. Low and high light was achieved through the use of shade cloths that decreased insolation by $80 \%$ and $20 \%$ respectively. Ambient sulfide (AS) cores hade no additions of sodium sulfide to the agar plates. Low sulfide (LS) cores had iron sulfide added to agar plates. High sulfide (HS) cores had sodium sulfide added to the agar. Each treatment was replicated five times. 


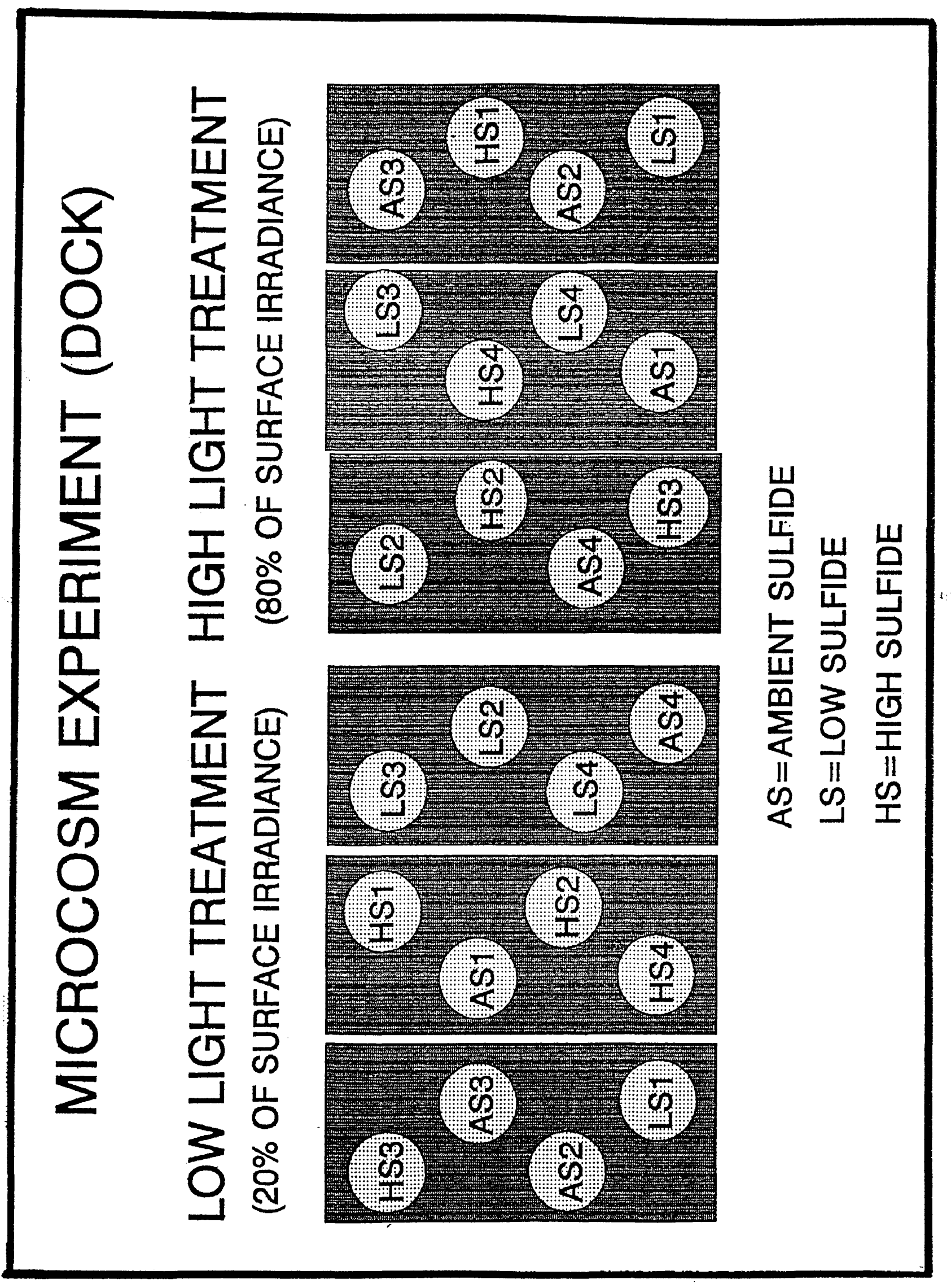


High, low, and ambient sulfide treatments were created in the microcosms. Ambient sulfide cores had no sulfide added to the agar, creating a control . High sulfide cores had amounts of sodium sulfide $\left(5 \mathrm{mM} \mathrm{Na}_{2} \times 9 \mathrm{H}_{2} \mathrm{O}\right)$ dissolved in the agar, again to create a maximum sulfide concentration of 1800um. Low sulfide cores had iron sulfide ( $4 \mathrm{mM} \quad \mathrm{FeSO}_{4}$ ) dissolved in the agar. It has been found that the accumulation of $\mathrm{H}_{2} \mathrm{~S}$ may be prevented in sediments containing reducible $\mathrm{Fe}$ because of the precipitation of sulfide as insoluble FeS (Connell \& Patrick 1968). The iron sulfide was thus added in an attempt to bind the ambient sulfide present, thus lowering the sulfide level of the sediment (Joshi \& Hollis 1977). Cores were placed randomly in the tanks corresponding to light treatments. Actual sulfide concentrations were again determined by sampling pore water through the use of the sippers. Each sulfide treatment was replicated three times at each light level. Net apparent photosynthesis was measured in the beginning of June 1991 $\left(T_{o}\right)$ and once a week for three weeks on the treated leaves. Two different light environments were created both in the field and the microcosm experiments. Both high light treatments represented ambient irradiance at the top of the plant canopy. The high light treatment in the field was left unmanipulated. A shade cloth on the pier decreased irradiance to about 55\% of surface insolation. The low light environments, both in the field and microcosm, corresponded 
to about $20 \%$ of surface irradiance in the field. This light compensation point of $20 \%$ of surface irradiance is typically the minimum amount of light eelgrass needs to survive. One shade cloth was used to achieve $20 \%$ of surface irradiance in the field, while a double cloth was placed over the cores in the microcosm experiment. The actual light intensities under the shades were measured weekly using a 4-PI light sensor. Light sensors with dataloggers that instantaneously measured light and recorded $\mathrm{uEm}^{-2} \mathrm{~s}^{-1}$ every fifteen minutes, were placed both in the field and on the dock for the month of June 1991 in Chincoteague Bay (Moore unpublished).

In the field and microcosm experiments, net apparent photosynthesis was measured by $\mathrm{O}_{2}$ evolution using a clarktype $\mathrm{O}_{2}$ electrode, Rank Brothers, Ltd. (Dennison \& Alberte 1982, Delieu \& Walker 1983, Marsh et al. 1986). This type of electrode apparatus is a polarographic cell driven by an externally generated potential difference over a cathode and an anode (Hootsman \& Vermaat 1991) and contains a stirring mechanism for constant stirring of the medium.

The growth rate of the eelgrass was determined prior to the beginning of the experiments. Two $2 \mathrm{~cm}$ leaf segments from each sample were placed in the electrode chamber. Each $2 \mathrm{~cm}$ leaf piece was taken from a segment on the second leaf, growth that occurred during the 21 days of the experiments. The electrode chamber contained continuously stirred, $\mathrm{O}_{2}$ depleted, filtered sea water. The water temperature in the 
chamber was kept at a constant temperature using a water bath system as the photosynthetic rate of seagrasses is affected by changes in water temperature (Marsh et al. 1986, Bulthius 1983, Kerr \& Strother 1985, Penhale 1977). The ambient water temperature in June of 1991 averaged $25^{\circ} \mathrm{C}$.

The relationship between light and photosynthesis was determined using neutral density filters and light from a 300w tungsten filter bulb. Light intensities ranged from 0$975 \mathrm{uEm}^{-2} \mathrm{~s}^{-1}$ and was measured using a 4-PI light sensor. The $\mathrm{O}_{2}$ electrode was attached to a strip chart recorder which recorded the output in $\mathrm{mV} \mathrm{cm}^{-1}$. This reading was converted to umol $\mathrm{O}_{2} \mathrm{~min}^{-1}$ sample $e^{-1}$.

Slopes $(y / x)$ of the converted strip chart measurements were plotted against the irradiance values to obtain a photosynthesis-irradiance (PI) curve for each sample. Dark respiration values were determined from the $\mathrm{O}_{2}$ output at zero irradiance. The $\mathrm{P}$-max was obtained by averaging the $\mathrm{O}_{2}$ evolution from the three highest light intensities. A least squares regression was used to estimate $I_{c}, I_{k}$, and the initial slope.

Following the measurement of apparent photosynthesis, the leaf segments were measured on a Licor model 3100 area meter to determine the actual area $\left(\mathrm{dm}^{2}\right)$ of the leaf segments. Chlorophyll content of the leaf segments were determined spectrophotometrically (Dennison 1990). The chlorophyll values and leaf area measurements were used to 
standardize the photosynthesis and respiration values obtained.

Measurement of the $\mathrm{O}_{2}$ changes within a medium is a common method used for estimating the photosynthetic rate of submersed vascular plants (Hootsman \& Vermaat 1991). However, determining the photosynthetic rate by measuring $\mathrm{O}_{2}$ evolution may be underestimated due to the possible internal storage of $\mathrm{O}_{2}$ in lacunar spaces within the plant (Roberts \& Moriarty 1987, Zieman 1974).

Seagrasses, as with other aquatic plants, lack stomata and have an interconnection of gas filled spaces called lacunae (Roberts \& Caperon 1986, Sorrell \& Dromgoole 1986, Smith et al 1988, Smith et al 1984). These spaces are prominent in plant organs which grow where ambient sediment $\mathrm{O}_{2}$ levels are low (Roberts \& McComb 1984). The lacunar cavities provide buoyancy for the plant and can entrap metabolic gases (Sculthorpe 1967). Since Hartman and Brown (1967) published their paper on the accumulation of $\mathrm{O}_{2}$ and $\mathrm{CO}_{2}$ in these lacunar spaces, there has been a controversy over the validity of using the $\mathrm{O}_{2}$ technique to accurately measure productivity in seagrasses (Kemp et al. 1986). It has been suggested that the presence of lacunae could cause an underestimation of photosynthesis measurements, which is based on changes in $\mathrm{O}_{2}$ concentration within the surrounding medium, as storage, recycling, or translocation of $\mathrm{O}_{2}$ occurs within these spaces (Kemp et al. 1986, Sorrell \& Dromgoole 
$1986)$.

Mechanisms for overcoming the problem of $\mathrm{O}_{2}$ storage in lacunae of seagrasses have been suggested. They include using both small pieces of plant material (Biebl \& McRoy 1971), and stimulating the $\mathrm{O}_{2}$ exchange rate by stirring the surrounding medium (Hootsman \& Vermaat 1991, sorrell \& Dromgoole 1986, Sand-Jensen et al 1982). Z. marina has a small lacunar volume and under well stirred conditions can reach steady state exchange with the surrounding medium in a matter of minutes (Sand-Jensen et al 1982). Drew (1978) and Wahbeh (1983) concluded errors in photosynthetic measurements using the $\mathrm{O}_{2}$ technique are small for most seagrasses under stirred conditions. In two different studies, Lipkin et al.(1986) and Kemp et al.(1986) both suggested that the measurement of the net exchange of $\mathrm{O}_{2}$ is a useful method for field studies due to its simplicity and direct measurement of dark respiration values.

In order to predict the effect of light availability on seagrass productivity and survival, the photosyntheticirradiance responses of the individual species must be understood. A photosynthesis-irradiance curve is a graphical or mathematical representation of the relationship between rates of measured photosynthesis and light. In general, seagrasses demonstrate a light limited phase of photosynthesis at low light intensities, a linear increase in photosynthesis as light increases, followed by a light 
saturation response at highest light intensities (Fourqurean \& Zieman 1991). These light response curves are used as predictors of net photosynthesis and growth (Hootsman \& Vermaat 1991, Dennison 1987, Dennison \& Alberte 1985).

Five parameters can be examined from the relationship between photosynthesis and irradiance. The photosynthetic maximum, P-max, is the rate of net photosynthesis at light saturation. It is the plateau height of the curve (Fourqurean \& Zieman 1991). Dark respiration rates are obtained from the point at which the PI curve intersects the $y$-axis at zero irradiance (Bulthius 1987). Quantification of respiration in the light, when using the oxygen evolution method is usually assumed to be equal to dark respiration (Hootsman \& Vermaat 1991, Fourqurean \& Zieman 1991). The rate of photosynthetic increase in response to increases in light, or the initial slope of the curve, is the third parameter. It is in this part of the curve where photosynthetic rate is directly proportional to light (Bulthius 1987). The light intensity at photosynthetic saturation $\left(I_{k}\right)$ reflects the adaptation of plants to light. Mathematically it is defined as P-max/initial slope (Fourqurean \& Zieman 1991). The light compensation point $\left(I_{c}\right)$ is where gross photosynthesis is equal to respiration; i.e., where net photosynthesis is zero.

The differences among all treatments in the field and microcosms, including the unmanipulated control in the field, 
were tested using a one-way ANOVA (Analysis of Variance). The interactive effect of light and sulfide manipulations were tested using a two-way ANOVA. Residual plots and Bartlett's test for homogeneity were also used in both analyses. 


\section{RESULTS}

The average PI curves from the microcosm and field experiments for each treatment level are shown in Figures 4 and 5. Both exhibit typical light limited phases, followed by a linear increase in $\mathrm{O}_{2}$ evolution as light increases, and leveling off near light saturation.

Photosynthetic parameters were examined on both a per unit chlorophyll and leaf area basis. The results here are presented on a per unit chlorophyll basis. All figures are shown per leaf area in Appendix A. There were no differences in chlorophyll to leaf area ratio among treatments and patterns of treatment response between the two were similar. The P-max and the dark respiration rates of the eelgrass segments were determined from direct measurements. $I_{c}, I_{k}$, and the initial slope of these curves were calculated using a linear regression. In addition to these photosynthetic parameters, total chlorophyll per area and the ratio of chlorophyll a/b were compared among treatments. The means and standard errors of these parameters from the field and microcosm are summarized in Appendix B.

The single and interactive effects of light and sediment sulfide treatments were determined using Analysis of Variance (ANOVA). The p-values are shown in Tables 1 and 2 . Lower $p-$ 
Figure 4: Graphical comparison of the mean PI curves for the six microcosm treatments and the mean PI curve from time zero. 


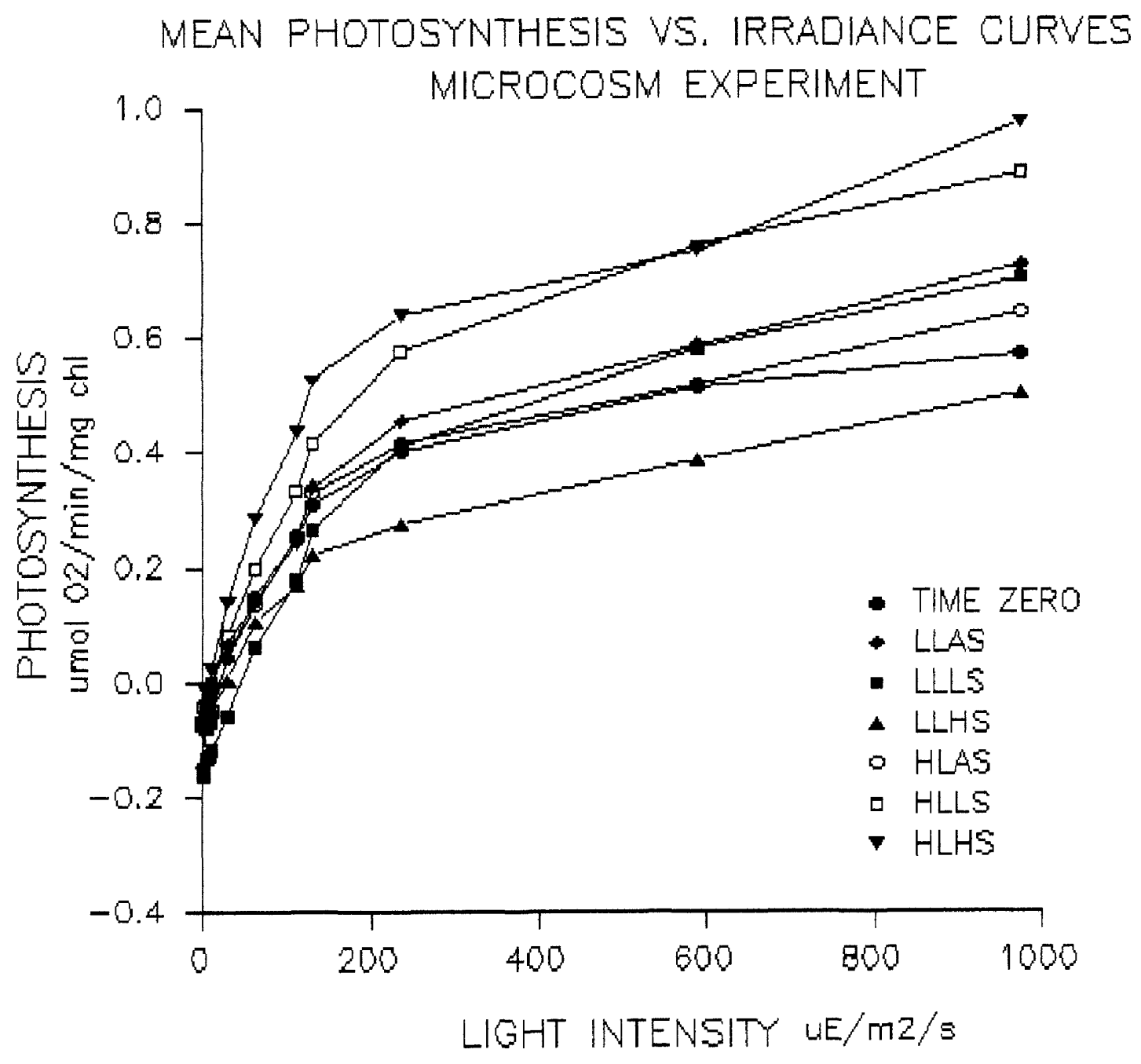


Figure 5: Graphical comparison of the mean PI curves for the five field treatments and the mean PI curve from time zero. 


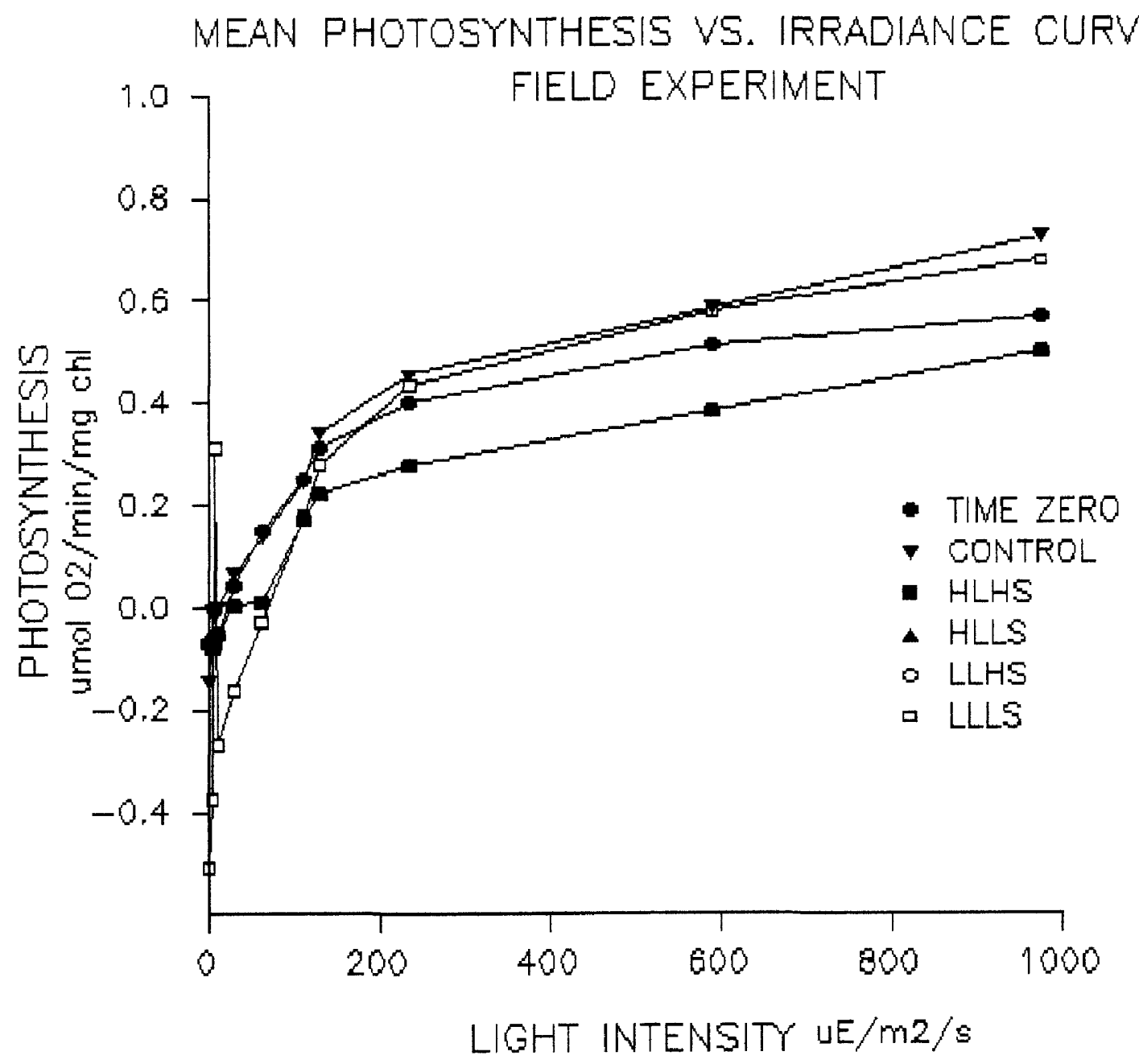


TABLE 1: 1-way and 2-way ANOVA p-values for PI parameters from Field Experiment.

p-Values

\begin{tabular}{|c|c|c|}
\hline \multirow[t]{4}{*}{ P-MAX } & Light & 0.42 \\
\hline & Sediment & 0.50 \\
\hline & Light $\mathrm{x}$ Sediment & 0.20 \\
\hline & 1-Way & 0.43 \\
\hline \multirow[t]{4}{*}{ RESPIRATION } & Light & 0.56 \\
\hline & Sediment & 0.52 \\
\hline & Light $\mathrm{x}$ Sediment & 0.88 \\
\hline & 1-Way & 0.53 \\
\hline \multirow[t]{4}{*}{$\mathbf{I}_{\mathrm{c}}$} & Light & 0.30 \\
\hline & Sediment & 0.68 \\
\hline & Light $\mathrm{x}$ sediment & 0.45 \\
\hline & 1-way & 0.10 \\
\hline \multirow[t]{4}{*}{$\mathbf{I}_{\mathbf{k}}$} & Light & 0.32 \\
\hline & Sediment & 0.37 \\
\hline & Light $x$ sediment & 0.21 \\
\hline & 1-Way & 0.50 \\
\hline \multirow[t]{4}{*}{ INITIAL SLOPE } & Light & 0.64 \\
\hline & Sediment & 0.30 \\
\hline & Light $\mathrm{x}$ sediment & 0.28 \\
\hline & 1-way & 0.58 \\
\hline \multirow[t]{4}{*}{ TOTAL CHLOROPHYLL } & Light & 0.75 \\
\hline & sediment & 0.92 \\
\hline & Light $\mathrm{x}$ Sediment & 0.69 \\
\hline & 1-Way & 0.95 \\
\hline \multirow[t]{4}{*}{ CHLOROPHYLL RATIO } & Light & 0.78 \\
\hline & Sediment & 0.25 \\
\hline & Light $\mathrm{x}$ Sediment & 0.78 \\
\hline & 1-Way & 0.71 \\
\hline
\end{tabular}


TABLE 2: 1-way and 2-way ANOVA p-values for PI parameters from Microcosm Experiment.

p-Values

\begin{tabular}{|c|c|c|}
\hline \multirow[t]{4}{*}{ P-MAX } & Light & 0.79 \\
\hline & Sediment & 0.55 \\
\hline & Light $\mathrm{x}$ sediment & 0.53 \\
\hline & 1-Way & 0.56 \\
\hline \multirow[t]{4}{*}{ RESPIRATION } & Light & 1.00 \\
\hline & Sediment & 0.57 \\
\hline & Light $x$ sediment & 0.33 \\
\hline & 1-Way & 0.82 \\
\hline \multirow[t]{4}{*}{$\mathbf{I}_{\mathrm{c}}$} & Light & 0.54 \\
\hline & sediment & 0.72 \\
\hline & Light $\mathrm{x}$ sediment & 0.51 \\
\hline & 1-way & 0.88 \\
\hline \multirow[t]{4}{*}{$\mathbf{I}_{\mathbf{k}}$} & Light & 0.49 \\
\hline & Sediment & 0.34 \\
\hline & Light $\mathrm{x}$ sediment & 0.47 \\
\hline & 1-Way & 0.34 \\
\hline \multirow[t]{4}{*}{ INITIAL SLOPE } & Light & 0.72 \\
\hline & Sediment & 0.69 \\
\hline & Light $x$ sediment & 0.88 \\
\hline & 1-Way & 0.53 \\
\hline \multirow[t]{4}{*}{ TOTAL CHLOROPHYLL } & Light & 0.63 \\
\hline & Sediment & 0.76 \\
\hline & Light $\mathrm{x}$ sediment & 0.71 \\
\hline & 1-Way & 0.77 \\
\hline \multirow[t]{4}{*}{ CHLOROPHYLL RATIO } & Light & 0.51 \\
\hline & Sediment & 0.48 \\
\hline & Light $\mathrm{x}$ sediment & 0.39 \\
\hline & 1-Way & 0.68 \\
\hline
\end{tabular}


values suggest statistical significance, or difference between treatments. It is inferred from the high p-values (> $0.05)$ for all parameters both in the field and microcosms that there is no statistically significant difference among treatment means.

Measured pore water sulfide concentrations for each replicate, both in the field and microcosm experiments, did not consistently reflect application rates in high sulfide and low sulfide treatments. This may explain the lack of difference $(p>0.05)$ observed among treatments. However, irrespective of application rates, a wide range in pore water sulfide (0-500uM in field and 0-1800uM in microcosms) was found among the individual cores.

Due to the lack of light response, it was possible to regroup the replicates from both experiments according to actual sulfide concentrations. The field replicates were combined across light levels and blocked in five groups of increasing looum ranges from 0 to $500 u$ m sulfide. The microcosm replicates also were arranged in five groups with the sulfide concentrations ranging from 0 to $1800 u$.

Linear regressions were calculated between measured concentrations of pore water sulfide and photosynthetic characteristics of $Z$. marina using these grouped means. The regression lines were tested for significance using a regression analysis. F-values were interpreted and although none of the parameters showed a significance at the 0.05 
level, there seems to be a significant response in the P-max $(f=0.07)$, respiration $(f=0.11)$, and total chlorophyll ( $f=0$. 12) from the microcosm experiment. All f-values from the field were higher than those from the microcosm. This is probably due to the higher sulfide concentrations achieved in the microcosms.

The P-max and initial slope plots from the field experiment are shown in Figure 6. Vertical and horizontal error bars show the standard errors for both the photosynthetic parameters and the grouped sulfide concentrations. A decrease is illustrated in both parameters with an increase in sulfide concentration. From the microcosm experiment, with a larger sulfide range, the trend suggests a decrease in P-max and respiration (Figure 7), as well as with the initial slope (Figure 8). No distinct difference was illustrated in the $I_{c}$ or $I_{k}$ with an increase in sulfide in the field. There is, however, an increasing trend in the $I_{c}$ and a decreasing trend in the $I_{k}$ with an increase in sulfide concentration in the microcosm experiment (Figure 9).

The total chlorophyll concentrations suggest an increase per leaf area with increasing sulfide concentration in the field and a decreasing trend in the ratio of chlorophyll $a / b$ (Figure 10). The increasing levels of chlorophyll concentrations with increasing sulfide levels was also observed in the microcosm plants (Figure 11). Total 
Figure 6: Mean P-max and initial slopes of the PI curves from the field experiment as a function of the mean grouped sulfide concentrations. Vertical and horizontal error bars show the standard errors for all parameters. 
PMAX AND INITIAL SLOPE FIELD EXPERIMENT
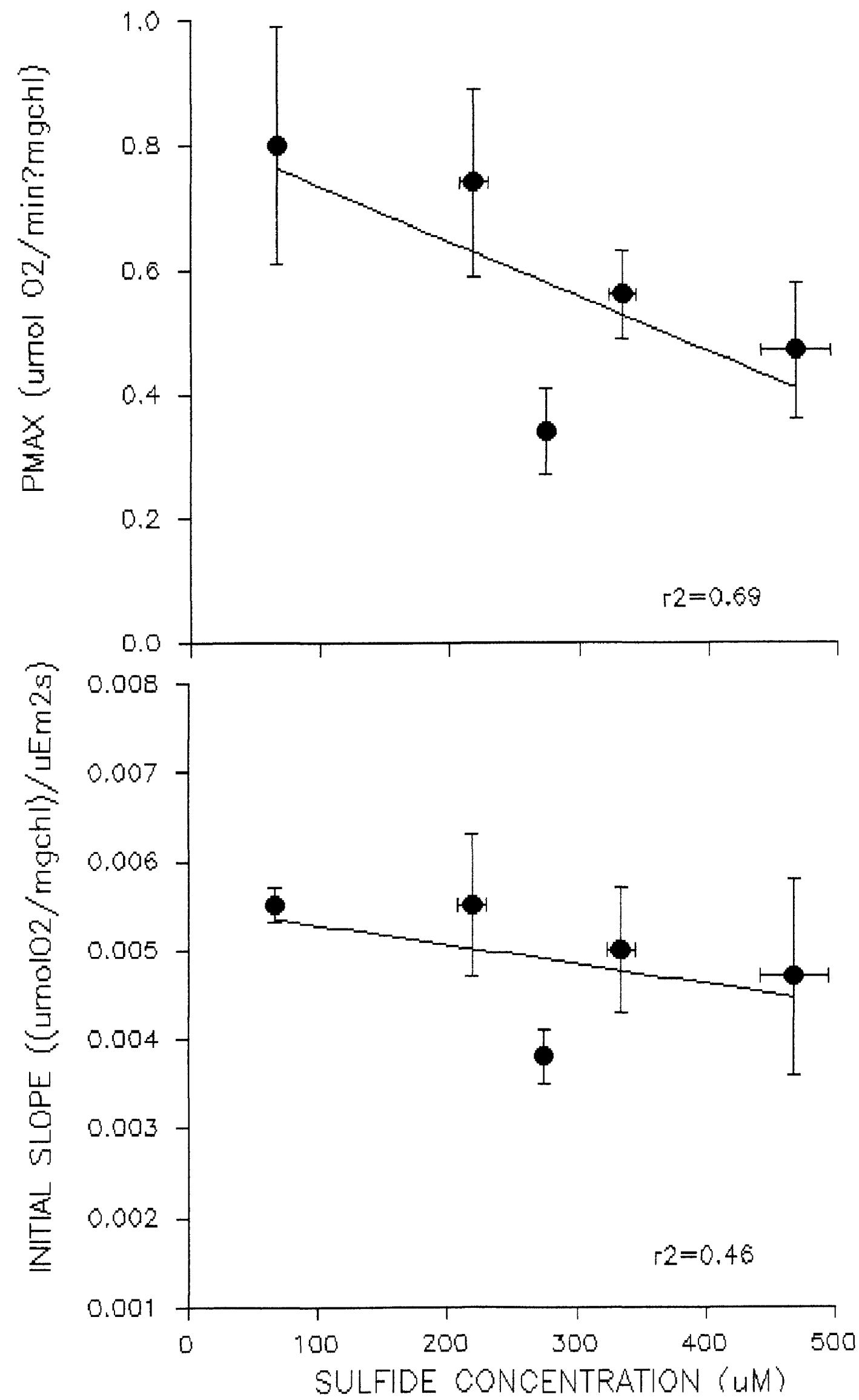
Figure 7: Mean P-max and respiration values, both in umol $\mathrm{O}_{2} \mathrm{~min}^{-1} \mathrm{mgchl}^{-1}$, as a function of mean grouped sulfide concentrations from the microcosm experiment. Vertical and horizontal error bars reflect the standard errors of all the parameters. 


\section{PHOTOSYNTHESIS AND RESPIRATION}
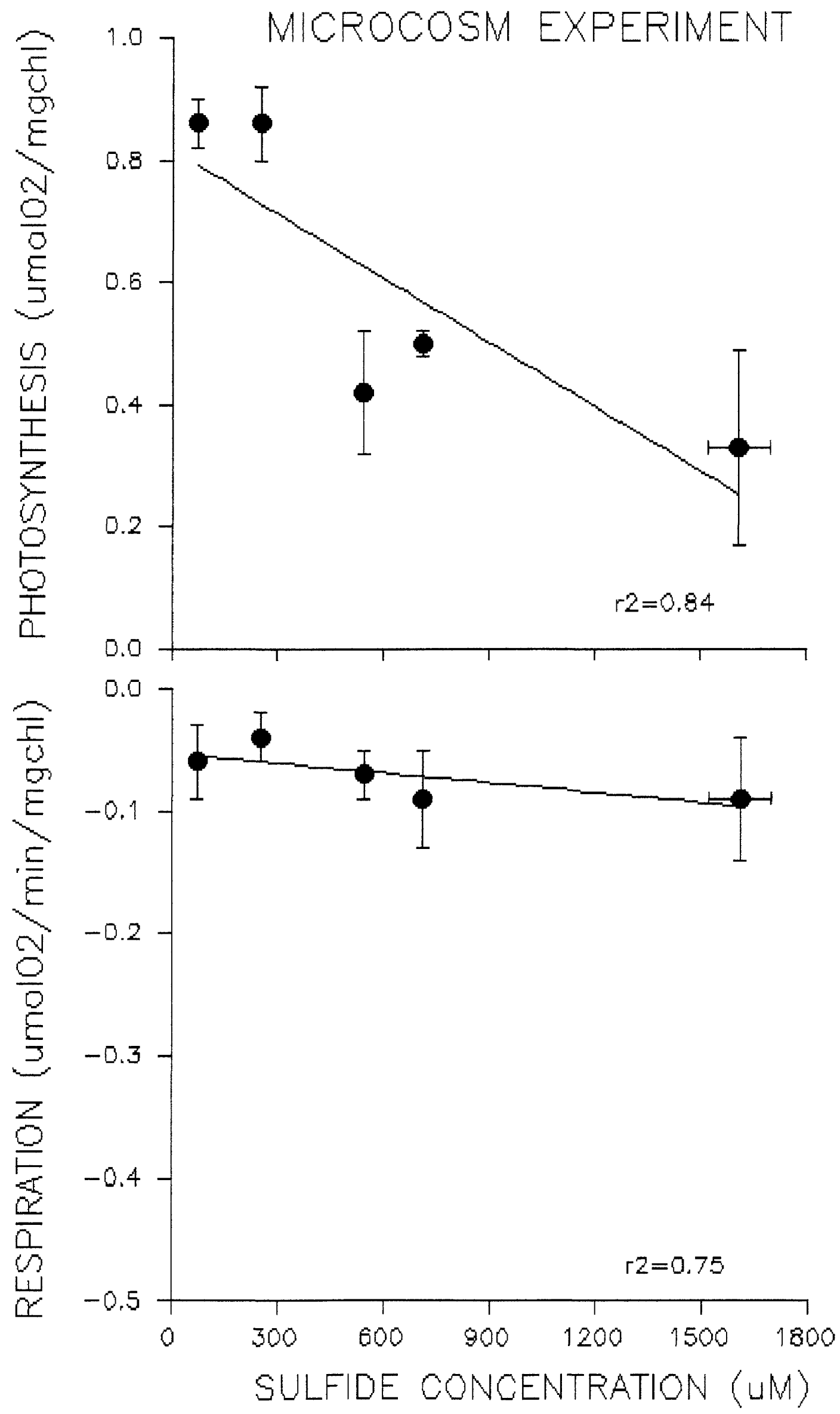
Figure 8: Relationship between the mean initial slopes and increasing sulfide grouped means from the microcosm experiment. Vertical and horizontal error bars show standard errors for both parameters. 


\section{INITIAL SLOPE-MICROCOSM EXPERIMENT}

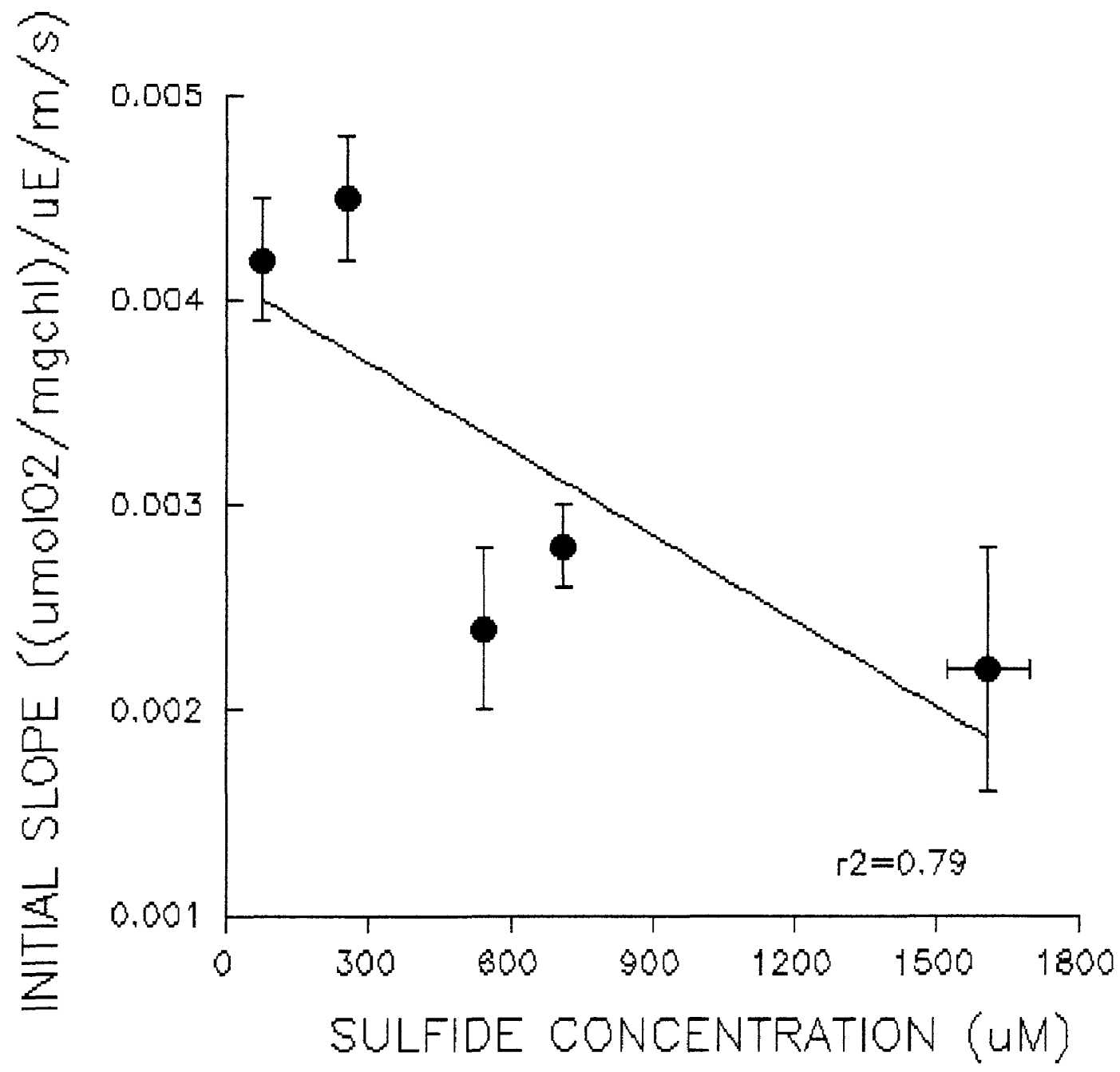


Figure 9: Effect of increasing sulfide grouped means on light compensation $\left(I_{c}\right)$ and light saturation $\left(I_{k}\right)$, both measured in $\mathrm{uEm}^{-2} \mathrm{~s}^{-1}$, points from the microcosm experiment. 

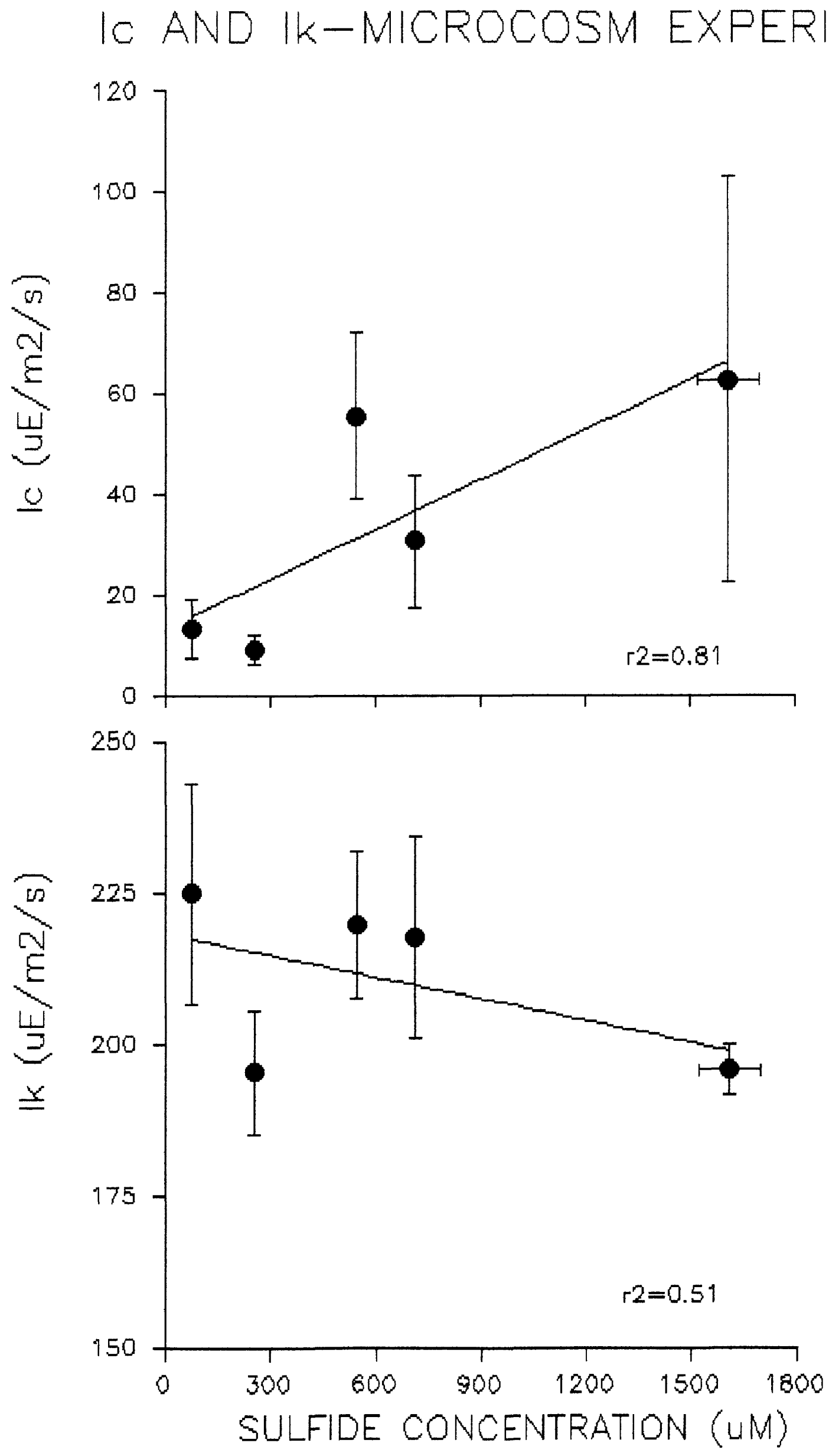
Figure 10: Mean total chlorophyll and ratios of chlorophyll $a / b$ as a function of the grouped mean sulfide concentrations from the field experiment. 
CHLOROPHYLL-FIELD EXPERIMENT
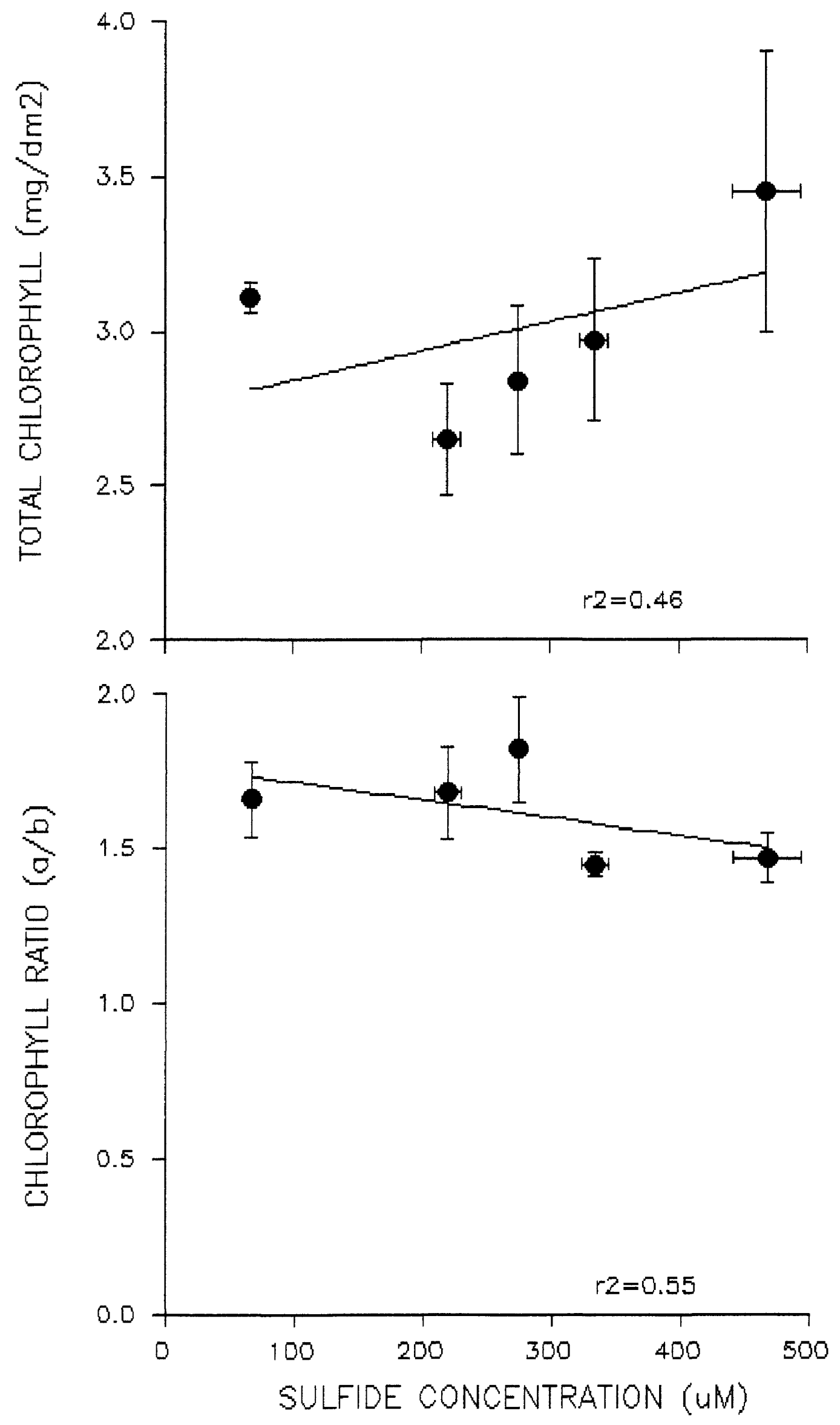
Figure 11: The relationship between mean total chlorophyll concentrations and increasing grouped mean sulfide concentrations from the microcosm experiment. 


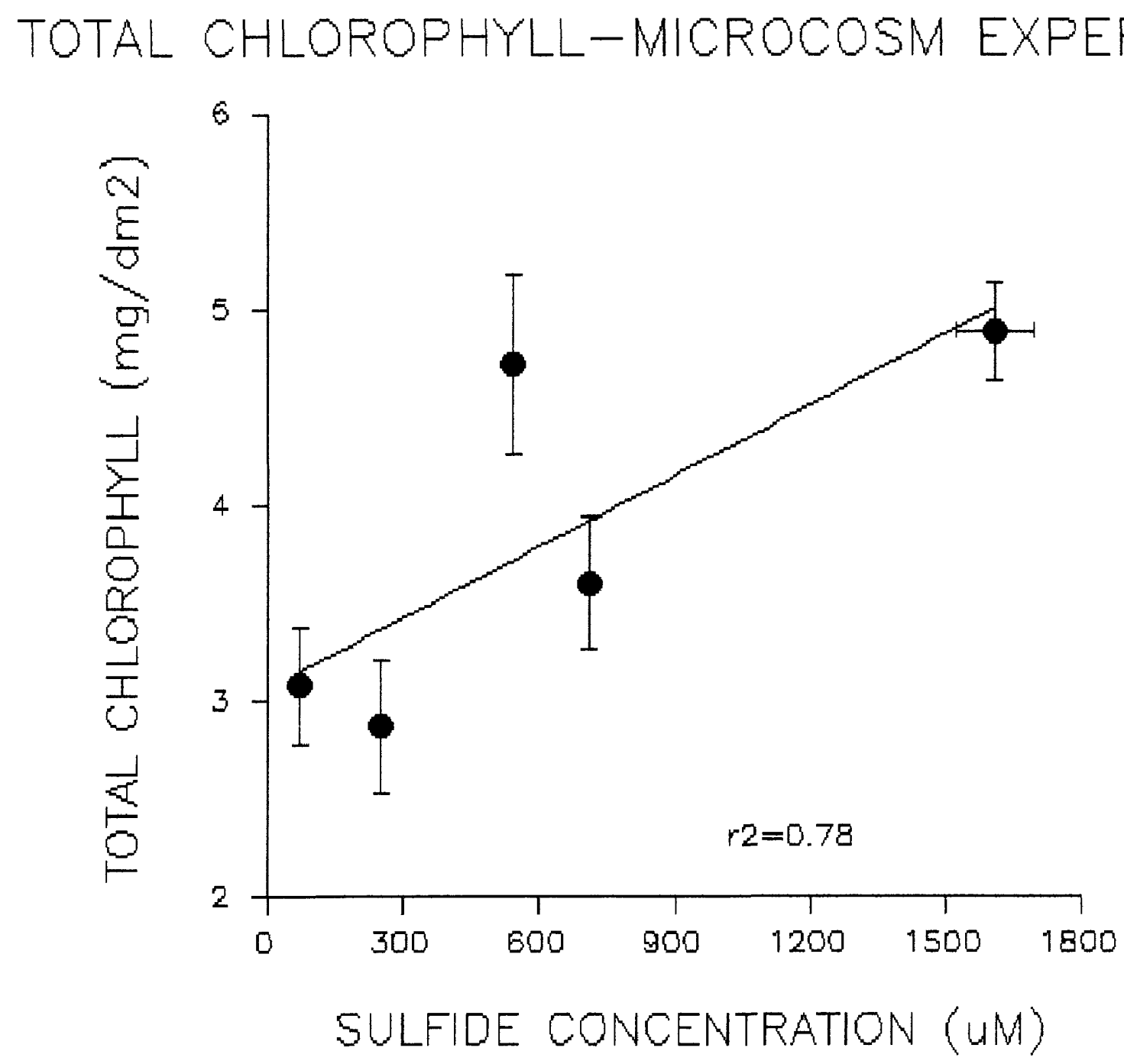


chlorophyll increasing with leaf area in these plants possibly implies a decrease in efficiency of light harvesting with an increase in sulfide concentration.Total chlorophyll levels may be increased in order to optimize light as shade adapted plants do under low light conditions.

The photosynthetic saturation point $\left(\mathrm{H}_{\text {sat }}\right)$ is that portion of the day that light intensities exceed the $I_{k}$. similarly, the photosynthetic compensation point $\left(\mathrm{H}_{\mathrm{comp}}\right)$ is the portion of the day where light intensities exceed the calculated $I_{c}$ (Dennison \& Alberte 1982). These two parameters should be considered when determining if the quantity of light for a particular time period was sufficient to allow normal photosynthetic activity.

From the light records for the month of June and average $I_{k}$ and $I_{c}$ values for both the field and microcosm experiments, $H_{s a t}$ and $H_{\text {conp }}$ could be determined. The actual daily calculated $H_{\text {comp }}$ values are shown in Figure 12 for both high and low light treatments for both experiments. Dennison \& Alberte $(1982,1985,1987)$ report that $H_{\text {comp }}$ values determined using individual leaf segments should average approximately 12 hours per day for the plants to receive sufficient light for normal photosynthetic activity to occur. High light treatments both in the field and microcosm experiments experienced only one or no days of compensating light below 12 hours in June of 1991. The plants grown under low light conditions averaged 10.9-11.3 hours of light above the $I_{c}$. 
Dennison \& Alberte have published several papers comparing these calculated $\mathrm{H}_{\text {sat }}$ and $\mathrm{H}_{\text {comp }}$ values under similar low and high light treatments in Great Harbor, Woods Hole, Massachusetts. These values for woods Hole and those calculated in this study for Chincoteague Bay are shown in Table 3 .

Minimal $H_{\text {sat }}$ values, with photon flux density sufficient to saturate the leaves, has been determined to be approximately 6 hours (Dennison \& Alberte 1985). The mean high light treatment $H_{\text {sat }}$ values both in the field and microcosm, greatly exceed this 6 hour minimum. The mean low light treatment $\mathrm{H}_{\text {sat }}$ values are just below the 6 hour minimum. In fact, these plants were exposed to saturating light for 12 and 10 days in the field and microcosm respectively during the month of study.

The lack of a light response seen in this study is possibly explained by these calculated $H_{\text {sat }}$ and $H_{\text {comp }}$ values. Even plants grown under low light still experienced adequate hours of compensating and saturating light to maintain normal photosynthetic rates. Although the low light treatments attempted to reduce the available light below the light compensation point for seagrasses, they actually received enough hours of quality light to exhibit no significant difference in photosynthetic parameters as a function of decreased light. 
Figure 12: Daily calculated mean $H_{\text {comp }}$ values for the high and low light treatments both in the field and microcosm experiments for the month of June 1991 in Chincoteague Bay. 


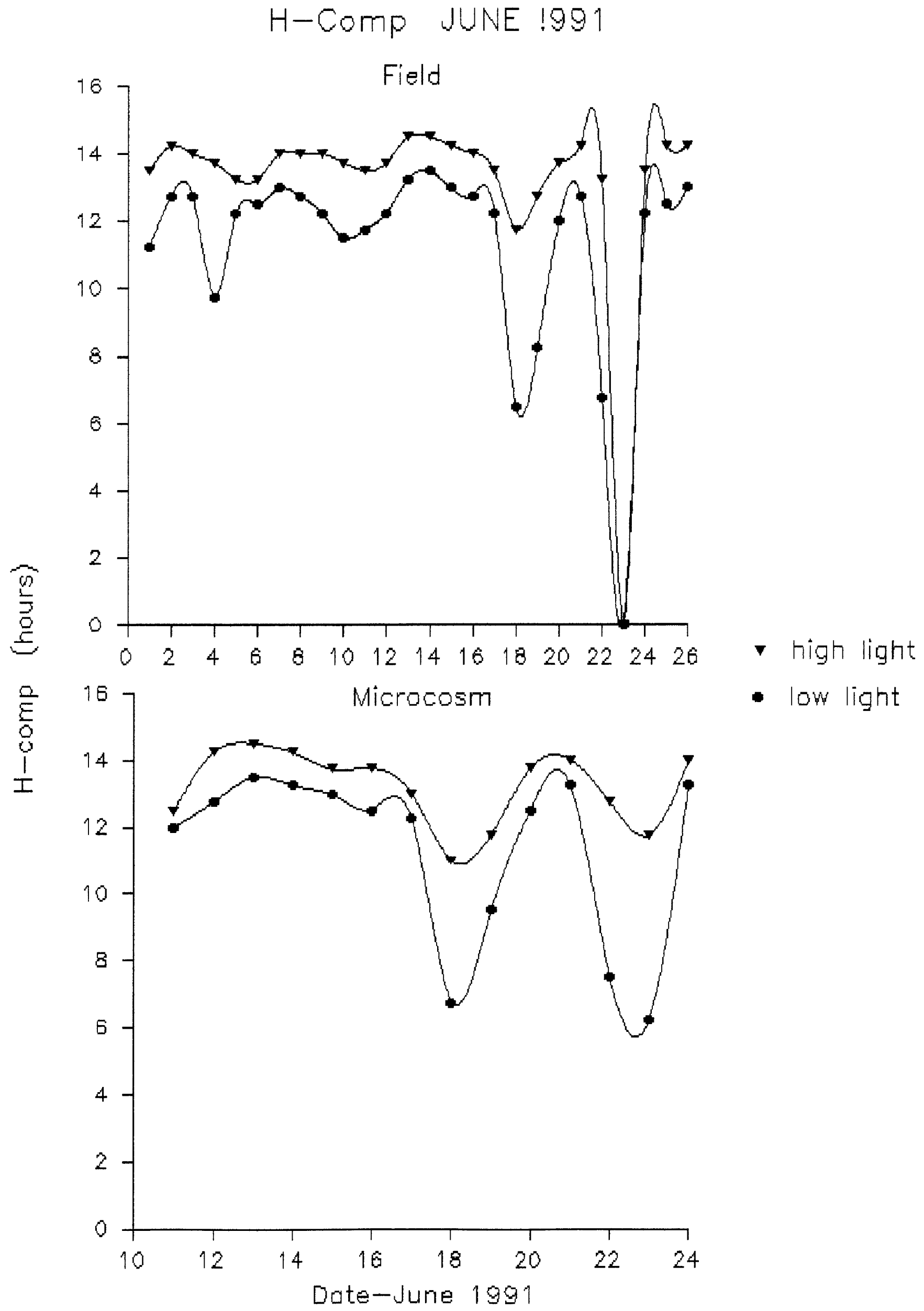


TABLE 3: Comparison of $\mathrm{H}$-comp and $\mathrm{H}$-sat in hours between Chincoteague Bay and Great Harbor, Woods Hole, Massachusetts (Dennison \& Alberte).

\begin{tabular}{|l|cc||cc||}
\hline & \multicolumn{2}{|c|}{ H-COMP } & \multicolumn{2}{c|}{ H-SAT } \\
\hline \hline \multirow{3}{*}{ CHINCOTEAGUE } & HIGH & LOW & HIGH & LOW \\
WOODS HOLE & 13.21 & 11.29 & 10.73 & 5.39 \\
& 12.60 & 10.90 & 12.70 & 5.80 \\
\hline
\end{tabular}




\section{DISCUSSION}

Plants adapted to lower light environments display different morphological characteristics compared to their higher light counterparts. For example, aquatic angiosperms that are adapted to lower light typically increase their leaf area and become thinner in order to intercept more light (Goldsborough \& Kemp 1988, Spence \& Crystal 1970) and freshwater macrophytes of the genus Potamogeton increase leaf area up to three fold when grown under low light (spence \& Crystal 1970). Plant adaptations to light may also be observed from changes in pigment concentrations, photosynthetic parameters, and in their response to differences in daily light periods. Examining light adaptations of seagrasses helps to better understand the variability of the environment in which it survives.

In this study, pigment concentrations of plants from high light treatments showed no significant difference in total chlorophyll levels. This is contrary to other studies. For example, marine diatoms, green algae, and freshwater macrophytes all increase chlorophyll content with decreases in light (Kirk 1983, Dring 1986). Eelgrass leaf tissue from Woods Hole, Massachusetts also displays an increase in total chlorophyll under low light conditions (Dennison \& Alberte 1985). The lack of difference in pigment concentration 
between high and low light plants in this study may be due to the fact that these plants are already adpted to very low light or perhaps the duration of the experiments were too short to allow these angiosperms to adapt.

After 21 days, the eelgrass in Chincoteague Bay displayed no differences in all the photosynthetic parameters in low and high light treatments. Marine algae found growing in lower light level their photosynthetic rate and reach saturation at lower light intensities compared to their higher light counterparts (Kirk 1983). The higher light adapted algae require more light to reach saturation (Kirk 1983). Studies on marine algae, freshwater submersed plants, and $z$. marina have found differences in the photosynthetic characteristics with reductions in light to levels near saturation (Dennison \& Alberte 1985, Dring 1986). These photosynthetic adaptations occur within 24 hours in most algae (Kirk 1983).

A lower respiration rate is often associated with plants that are grown under shaded conditions (Dring 1986). Diatoms and most algae exhibit this characteristic (Kirk 1983). Dark respiration is decreased by about a third in species of Potamogeton (Spence \& Crystal 1970). With this lower respiratory rate in shade adapted plants, comes a decreased light compensation point $\left(I_{c}\right)$. This is due to the fact that the $I_{c}$ is where photosynthesis is equal to respiration (Spence \& Crystal 1970). 
With an increase in pigment concentration in shade adapted seagrasses comes a reduction in the initial slope of the PI curve (Dring 1986). This is partly due to the fact that the more concentrated the pigments become, the less efficiently they collect light, thus lowering the measure of the light gathering efficiency or the initial slope (Kirk $1983)$.

As was illustrated previously in Figure 12, the daily light periods, $\mathrm{H}_{\text {comp }}$ and $\mathrm{H}_{\text {sat }}$, were different between high and low light treatments. Similar results were also found in a study using eelgrass segments in a more northern coastal habitat (Dennison \& Alberte 1985). However, the eelgrass in these other studies displayed differences in photosynthetic characteristics as a function of light, most notably an increase in chlorophyll concentration in shade adapted leaves (Dennison \& Alberte 1985). The decrease of $H_{\text {sat }}$ and $H_{\text {comp }}$ in the low light plants from Chincoteague Bay was enough to cause a difference in growth (Kuhn 1992), but not a difference in the photosynthetic response. The variable daily light regime of Chincoteague Bay may have caused these plants to adapt differently than other plants in similar habitats. It may be that the eelgrass has developed a plasticity and can therefore adapt on a daily basis to changes in light. The low light plants from both experiments experienced several days where their $H_{\text {comp }}$ and $H_{\text {sat }}$ were well below 12 hours and 6 hours respectively, the time Dennison \& 
Alberte (1985) have established to be optimal for eelgrass leaf tissue. The several days above the optimal daily light periods were enough to allow these plants to make it through the extremely low light days. It seems these plants have other ways of overcoming or adapting to the highly variable light.

Other studies have addressed the question of the effect of increased levels of sediment sulfide on the growth and production of wetland plants (Koch \& Mendelssohn 1989, Joshi \& Hollis 1977). However, the effect of the photosynthetic response of plants to increased levels of sediment sulfide has never been addressed.

In both experiments, a decrease in $\mathrm{P}$-max was observed with increasing sulfide levels. The trend is more obvious from the microcosm experiment where the range of sulfide concentrations was higher. One mechanism for this reduction in P-max may be inhibition of enzymes controlling the dark reaction of photosynthesis, such as Rubisco. The P-max of seagrasses and other plants is controlled by the processing time of the dark reaction of photosynthesis (Salisbury \& Ross 1985). The Calvin Cycle, as the dark reaction is commonly called, is enzyme controlled. Ribulose bisphosphate carboxylase (Rubisco), is the enzyme which catalyzes the combination of $\mathrm{CO}_{2}$ with ribulose 1,5 bisphosphate (RuBP) to form other sugar phosphates and converts some carbon back to RuBP in the Calvin Cycle (Osmond et al. 1980). 
The efficiency by which light of low intensities can be utilized in photosynthesis is indicated by the initial slope of the PI curve (Williams \& MCRoy 1982). With increases in sulfide concentrations in this study, this efficiency is reduced. It seems with a higher stress of sediment sulfide, the eelgrass loses its efficiency to photosynthesize at lower light levels. Higher concentrations of sediment sulfide, greater than 500um, of the microcosm experiment caused a more drastic decline in the initial slope.

An increase in chlorophyll concentrations was found both in the field and microcosm experiments, with again a more obvious trend from the microcosm. Total chlorophyll increasing with leaf area in these plants implies a decrease in efficiency of light harvesting with an increase in sulfide concentration. The initial slope, which was previously described as the efficiency of utilization of light, also implies this decrease in light capturing efficiency as sulfide levels are increased. Total chlorophyll levels may be increased in order to optimize light gathering as shade adapted plants do under low light conditions (Kirk 1983, Dring 1986).

No trend was observed in the respiratory rate of eelgrass with increasing levels of sulfide from the field experiment. The respiration rate increased with an increase in sulfide in the microcosm experiment (ie. more $\mathrm{O}_{2}$ was consumed per unit chlorophyll). This implies either the 
respiratory demand may be increasing with increased stress of sediment sulfide or that there is an increase in $\mathrm{O}_{2}$ consumption per unit chlorophyll. In the first, the maintenance cost of the plants may be increased as more $\mathrm{O}_{2}$ is transported from shoots to roots to replace $\mathrm{O}_{2}$ that is pumped into the root rhizosphere. Plants exposed to anoxic root environments must have a means for internal $\mathrm{O}_{2}$ transport to maintain aerobic root respiration (Koch et al. 1990). Alternatively, the second implication would mean there is less chlorophyll in leaves exposed to higher levels of sulfide. Previous comparison of chlorophyll leaf area data revealed that chlorophyll per leaf area increases, not decreases, with an increase in sediment sulfide. Therefore, it is assumed that the maintenance cost (ie. respiratory demand) is increased with an increase in sulfide concentration. 


\section{CONCLUSIONS}

Despite the lack of significant results, the trends displayed in the photosynthetic response of eelgrass to increases in sediment sulfide are obvious. There was no photosynthetic response of the eelgrass to decreases in light over a 21 day period. This may be due to the ability of the plants in Chincoteague Bay to adapt daily to variable light. It seems there were adequate hours of light, even in the low light treatments, above the $\mathrm{H}_{\text {comp }}$ and $\mathrm{H}_{\text {sat }}$ requirements on an average over the study period to allow these plants to photosynthesize at normal levels.

The $\mathrm{P}-\mathrm{max}$ is reduced in leaves exposed to treatments of sulfide above 500um. This, again, may be due to the inhibition of enzymes involved in the dark reaction of photosynthesis, which controls the P-max. The respiratory demand of the eelgrass is increased with sediment sulfide levels above 500uM. There is more $\mathrm{O}_{2}$ consumed per unit chlorophyll. This implies that the maintenance cost of the plants is increased as more $\mathrm{O}_{2}$ is transported from the shoots to the root rhizosphere. Total chlorophyll is also increased with sulfide concentrations above 500uM. This increase along with a decrease in the initial slope implies a decrease in efficiency of light harvesting as sediment sulfide is increased. Total chlorophyll levels are increased in order to optimize light harvesting. 
APPENDIX A: Photosynthetic parameters (P-max, initial slope, respiration, $I_{c}$, and $I_{k}$ ) shown on a per leaf area basis for the field and microcosm experiments. 
PMAX AND INITIAL SLOPE- FIELD

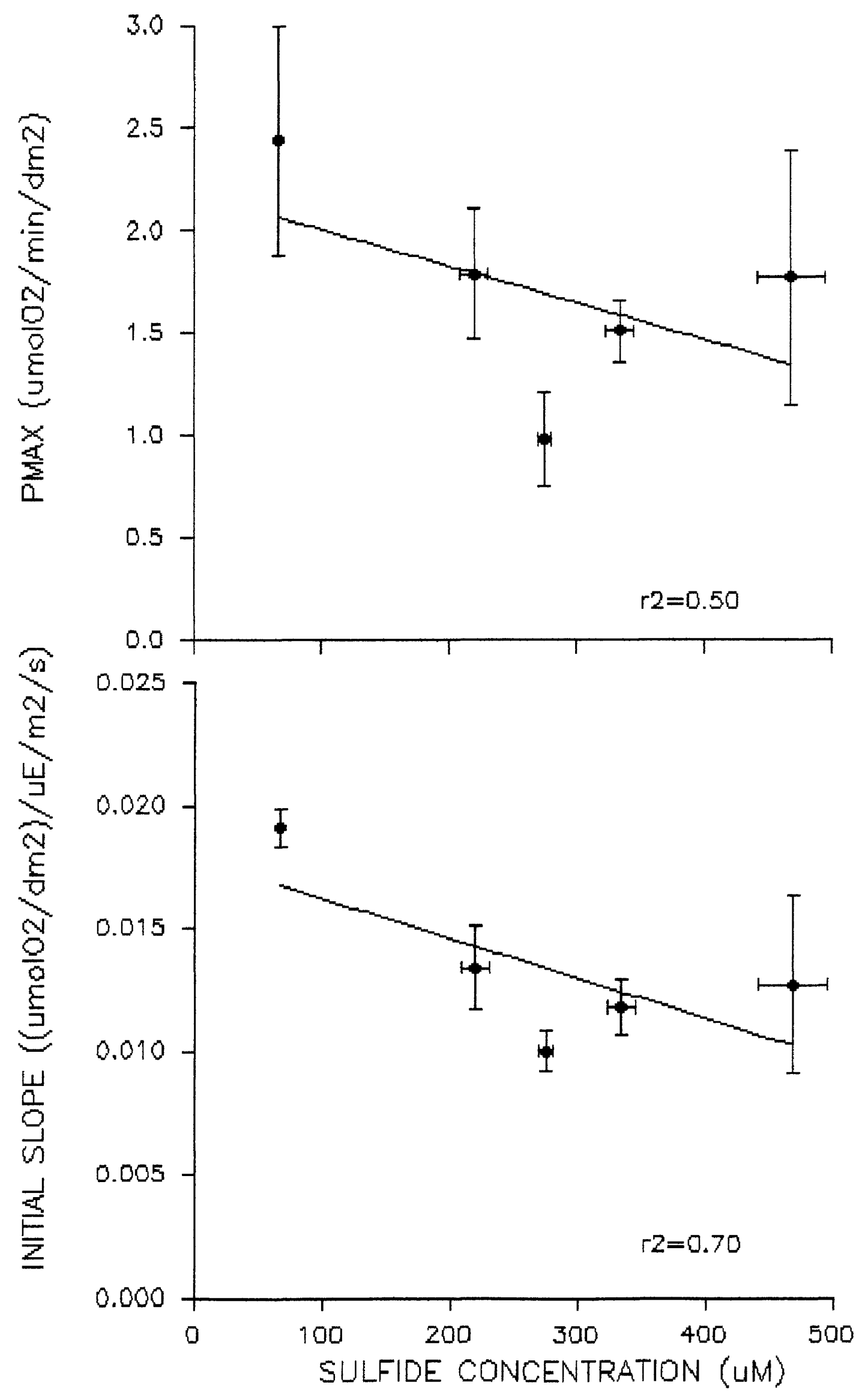


PHOTOSYNTHESIS AND RESPIRATION-MICROCOSM
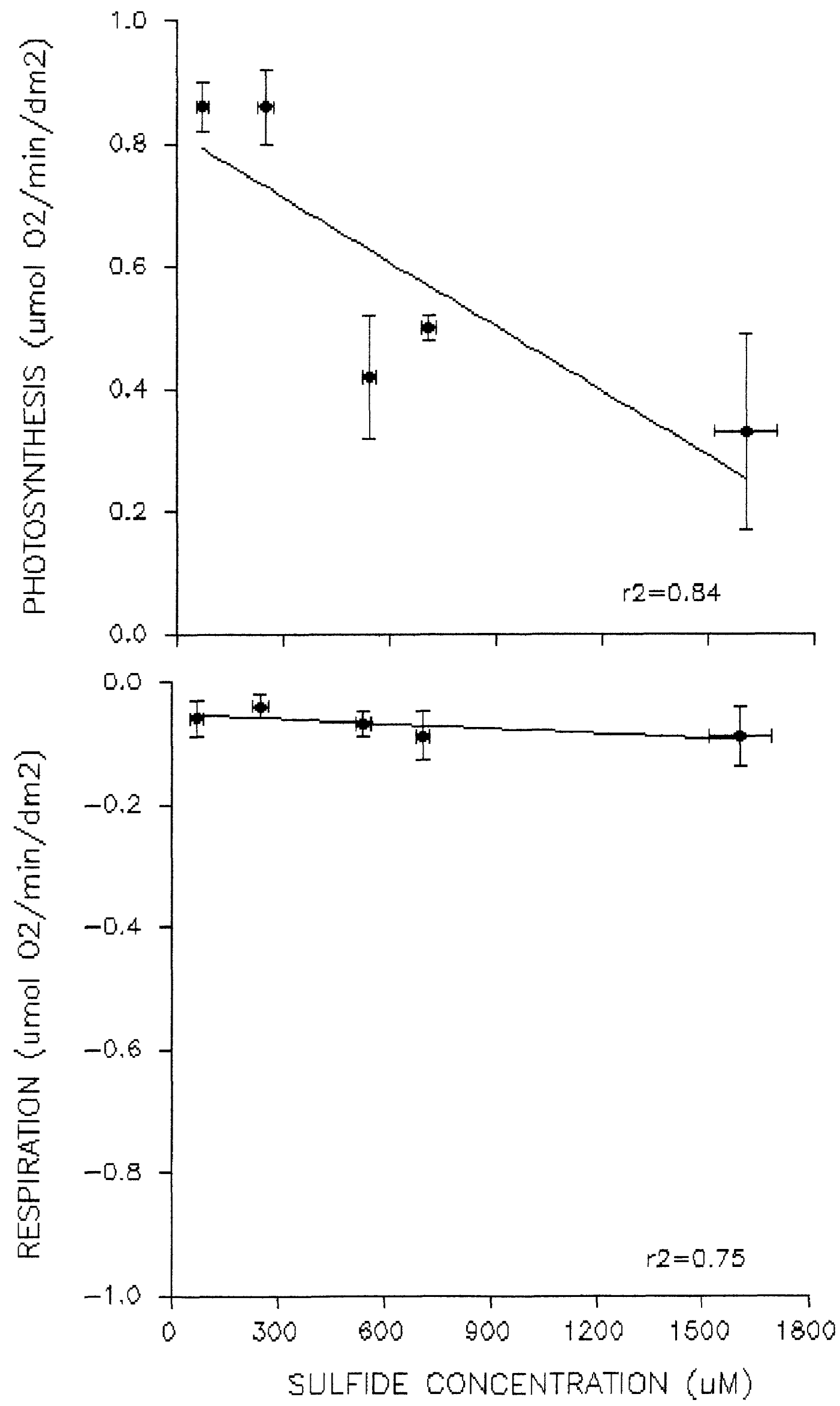
INITIAL SLOPE-MICROCOSM

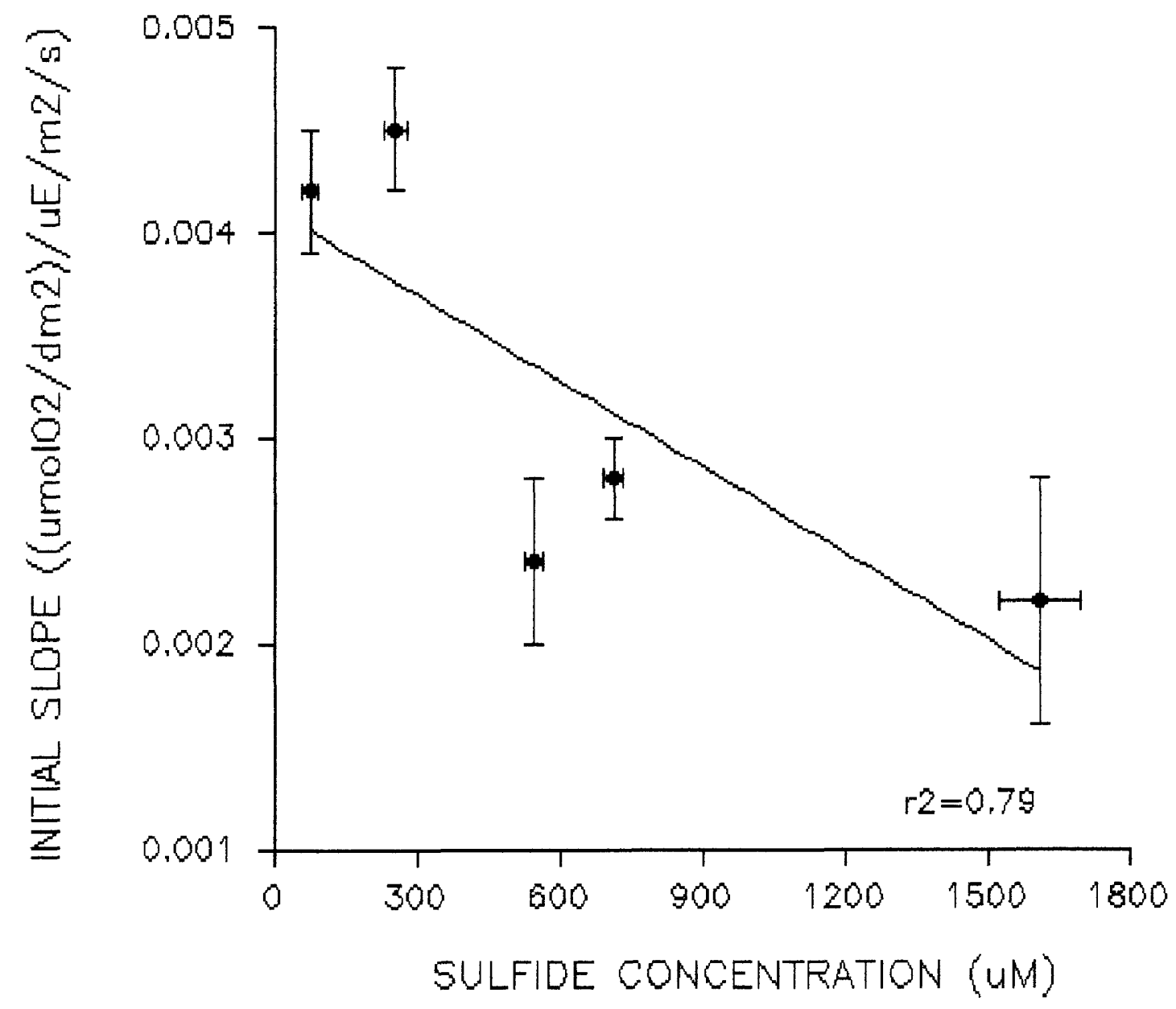




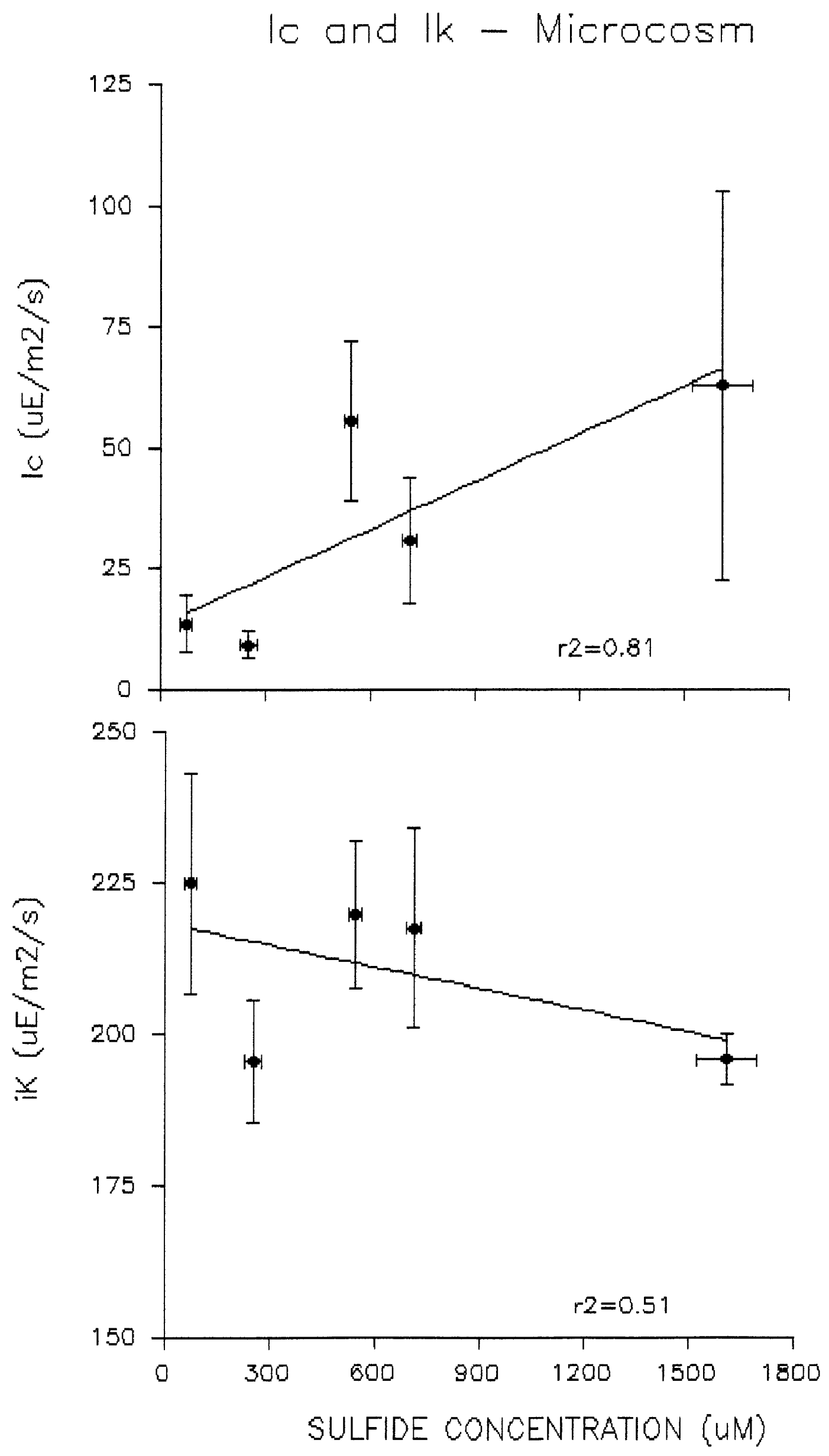




\section{APPENDIX B}

The following tables summarize the means and standard errors of the photosynthetic parameters per unit chlorophyll for the field and microcosm experiments.

TABLE B-1: Maximum net photosynthesis and dark respiration as a function of sulfide and light treatments in eelgrass leaves from microcosm experiment. (umol $0_{2} \mathrm{~min}^{-1} \mathrm{mg} \mathrm{chl} \mathrm{c}^{-1}$ )

\begin{tabular}{|c|c|c|c|c|c|c||}
\hline & LLAS & LLLS & LLHS & HLAS & HLLS & HLHS \\
\hline \hline $\begin{array}{c}\text { P-MAX } \\
\text { (STD.ERROR) }\end{array}$ & $\begin{array}{c}0.59 \\
(0.11)\end{array}$ & $\begin{array}{c}0.58 \\
(0.03)\end{array}$ & $\begin{array}{c}0.39 \\
(0.07)\end{array}$ & $\begin{array}{c}0.53 \\
(0.10)\end{array}$ & $\begin{array}{c}0.74 \\
(0.05)\end{array}$ & $\begin{array}{c}0.79 \\
(0.08)\end{array}$ \\
\hline $\begin{array}{c}\text { RESPIRATION } \\
(\text { STD. ERROR })\end{array}$ & $\begin{array}{c}0.05 \\
(0.01)\end{array}$ & $\begin{array}{c}-0.10 \\
(0.03)\end{array}$ & $\begin{array}{c}-0.07 \\
(0.02)\end{array}$ & $\begin{array}{c}-0.07 \\
(0.02)\end{array}$ & $\begin{array}{c}-0.04 \\
(0.01)\end{array}$ & $\begin{array}{c}-0.08 \\
(0.01)\end{array}$ \\
\hline
\end{tabular}

TABLE B-2: Maximum net photosynthesis and dark respiration as a function of sulfide and light treatments in eelgrass leaves from field experiment. (umol $\mathrm{O}_{2} \mathrm{~min}^{-1} \mathrm{mg} \mathrm{chl}^{-1}$ )

\begin{tabular}{|c|c|c|c|c|c||}
\hline & CONTROL & HLHS & HLLS & LLHS & LLLS \\
\hline \hline P-MAX & 0.6773 & 0.3346 & 0.6402 & 0.6623 & 0.5637 \\
(STD.ERROR) & $(0.09)$ & $(0.06)$ & $(0.15)$ & $(0.05)$ & $(0.21)$ \\
\hline RESPIRATION & -0.1366 & -0.2450 & -0.3457 & -0.3393 & -0.4014 \\
$($ STD.ERROR $)$ & $(0.06)$ & $(0.04)$ & $(0.15)$ & $(0.12)$ & $(0.11)$ \\
\hline
\end{tabular}


TABLE B-3: Grand means and standard errors of total chlorophyll ( $\mathrm{a}+\mathrm{b}$ ) and chlorophyll $\mathrm{a} / \mathrm{b}$ ratios for eelgrass leaves as a function of light and sulfide treatments from microcosm experiment.

\begin{tabular}{||c|c|c|c|c|c|c||}
\hline & LLAS & LLLS & LLHS & HLAS & HLLS & HLHS \\
\hline \multirow{2}{*}{$\begin{array}{c}\text { *TOTAL } \\
\text { CHLOROPHYLL }\end{array}$} & $\begin{array}{c}3.51 \\
(0.63)\end{array}$ & $\begin{array}{c}3.57 \\
(0.11)\end{array}$ & $\begin{array}{c}4.57 \\
(0.18)\end{array}$ & $\begin{array}{c}4.26 \\
(0.38)\end{array}$ & $\begin{array}{c}3.67 \\
(0.25)\end{array}$ & $\begin{array}{c}3.26 \\
(0.24)\end{array}$ \\
\hline **CHLOROPHYLL & 1.48 & 1.57 & 1.54 & 1.58 & 1.63 & 1.70 \\
RATIO & $(0.02)$ & $(0.02)$ & $(0.01)$ & $(0.06)$ & $(0.02)$ & $(0.02)$ \\
\hline
\end{tabular}

$\star \mathrm{mg} \mathrm{dm^{-2 }}$

$* * \mathrm{a} / \mathrm{b}$

TABLE B-4: Grand means and standard errors of total chlorophyll $(\mathrm{a}+\mathrm{b})$ and chlorophyll $a / b$ ratios for eelgrass leaves as a function of light and sulfide treatments from field experiment.

\begin{tabular}{||c|c|c|c|c|c|}
\hline & CONTROL & HLHS & HLLS & LLHS & LLLS \\
\hline \hline *TOTAL & 3.103 & 3.017 & 2.855 & 2.773 & 2.867 \\
CHLOROPHYLL & $(0.13)$ & $(0.07)$ & $(0.21)$ & $(0.41)$ & $(0.42)$ \\
\hline $\begin{array}{c}\text { * CHLOROPHYLL } \\
\text { RATIO }\end{array}$ & 1.586 & 1.561 & 1.709 & 1.465 & 1.714 \\
& $(0.06)$ & $(0.04)$ & $(0.19)$ & $(0.04)$ & $(0.22)$ \\
\hline
\end{tabular}

*mg $\mathrm{dm}^{-2}$

$* * a / b$ 
TABLE B-5: Compensation Irradiance $\left(I_{C}\right)$, Light Saturation Photon Flux Density $\left(I_{K}\right)$, and Initial Slope as a function of sulfide and light treatments in eelgrass leaves from microcosm experiment.

\begin{tabular}{||c|c|c|c|c|c|c||}
\hline & LLAS & LLLS & LLHS & HLAS & HLLS & HLHS \\
\hline$I_{\mathrm{c}} *$ & 38.01 & 45.93 & 46.25 & 39.13 & 14.93 & 16.77 \\
(STD.ERROR) & 14.6 & 7.3 & 17.3 & 13.8 & 4.3 & 3.9 \\
\hline$I_{\mathrm{k}} *$ & 225.27 & 229.93 & 201.63 & 195.93 & 230.77 & 188.67 \\
(STD.ERROR) & 13.7 & 5.98 & 3.23 & 5.88 & 9.15 & 13.7 \\
\hline INT.SLOPE** & 0.0029 & 0.0031 & 0.0023 & 0.0031 & 0.0035 & 0.0042 \\
(STD.ERROR ) & 0.0005 & 0.0001 & 0.0002 & 0.0004 & 0.0003 & 0.0004 \\
\hline
\end{tabular}

$* u \mathrm{Em}^{-2} \mathrm{~S}^{-1}$

$* *\left(\mathrm{umolO}_{2} \mathrm{mg}^{-1} \mathrm{Chl}^{-1}\right) / \mathrm{uEm}^{-2} \mathrm{~S}$

TABLE B-6: Compensation Irradiance $\left(I_{c}\right)$, Light Saturation Photon Flux Density $\left(I_{K}\right)$, and Initial Slope as a function of sulfide and light treatments in eelgrass leaves from field experiment.

\begin{tabular}{|c|c|c|c|c|c||}
\hline & CONTROL & HLHS & HLLS & LLHS & LLLS \\
\hline \hline$I_{\mathrm{c}} *$ & 28.249 & 89.254 & 62.307 & 95.64 & 103.95 \\
$(\mathrm{STD} . \mathrm{ERROR})$ & $(1.73)$ & $(1.49)$ & $(7.19)$ & $(2.4)$ & $(2.5)$ \\
\hline$I_{\mathrm{k}}{ }^{*}$ & 200.26 & 218.89 & 111.12 & 231.17 & 92.85 \\
$(\mathrm{STD} . \mathrm{ERROR})$ & $(43.85)$ & $(33.07)$ & $(14.35)$ & $(35.97)$ & $(17.85)$ \\
\hline INT.SLOPE** & 0.0050 & 0.0036 & 0.0057 & 0.0051 & 0.0051 \\
$(\mathrm{STD}$. ERROR $)$ & $(.0002)$ & $(0.0003)$ & $(0.0002)$ & $(0.0001)$ & $(.0004)$ \\
\hline
\end{tabular}




\section{REFERENCES}

Biebl, R. and C.P. McRoy. 1971. Plasmatic resistance and rate of respiration and photosynthesis of zostera marina at different salinities and temperatures. Mar.Biol. 8:48-56.

Boudouresque, C.F. and J. de Grissae. 1983. L'herbier a Posidonia oceanica en Mediterrance: les interactions entre la plante et le sediment. J. Rech. Oceanogr. 8(2,3):99-122.

Borum, J. 1985. Development of epiphytic communities on eelgrass (Zostera marina) along a nutrient gradient in a Danish Estuary. Marine Bioogy 87:211-18.

Bulthius, Douglas A. 1987. Effects of temperature on photosynthesis and growth of seagrasses. Aquatic Bot. 27:2740 .

Bulthius, Douglas A. 1983. Effects of temperature on the photosynthesis-irradiance curve of the Australian seagrass, Heterozostera tasmanica. Mar.Biol.Lett. 4:47-57.

Bulthius, D.A. and W.J. Woelkerling. 1983. Biomass accumulation and shading effects of epiphytes on leaves of the seagrass Heterozostera tasmanica in Victoria, Australia. Aquatic Bot. 16:137-148.

Chambers, P.A. and J. Kalff. 1985. Depth distribution and biomass of submersed aquatic macrophyte communities in relation to secchi depth. Can.J.Fish.Aqu.Sci. 42:701-709.

Chambers, P.A. and E.E. Prepas. 1988. Underwater spectral attenuation and its effect on the maximum depth of angiosperm colonization. Can.J.Fish.Aqu.Sci. 45:1010-1017.

Connel1, W.E. and W.H. Patrick,Jr. 1968. Sulfate reduction in soil: Effects of Redox potential and pH. Science 159:86-87.

Cooper, A. 1984. A comparative study of the tolerance of salt marsh plants to manganese. Plant \& Soil 81:47-59.

Dawes, C.J. and D.A. Tomasko. 1988. Depth distribution of Thalassia testudinum in two meadows on the west coast of Florida; a

difference in effect of light availability. Mar.Ecol. $9(2): 123-130$.

Delaune, R.D., C.J. Smith, M.D. Tolley. 1984. The effect of 
sediment redox potential on nitrogen uptake, anaerobic root respiration and growth of Spartina alterniflora. Aquatic Bot. $18: 223-230$.

Delieu, T.J. and D.A. Walker. 1983. Simultaneous measurement of oxygen evolution and chlorophyll flourescence from leaf pieces. Plant Physiol. 73:534-541.

den Hartog, C. 1970. The Seagrasses of the world. London: North-Holland Publ. Co. $275 \mathrm{pp}$.

Dennison, William C. 1987. Effects of light on seagrass photosynthesis, growth and depth distribution. Aquatic Bot. $27: 15-26$.

Dennison, W.C. 1990. Chlorophyll content. In: R.C. Phillips and C.P. McRoy (eds) Seagrass Research Methods. Unesco, Paris, France. pp.83-85.

Dennison, W.C. and R.S. Alberte. 1985. Role of daily light period in the depth distribution of Zostera marina (eelgrass). Mar.Ecol.Prog.Ser. 25:51-61.

Dennison, W.C. and R.S. Alberte. 1982. Photosynthetic responses of Zostera marina to in situ manipulations of light intensity. Oecologia 55:137-144.

Drew, E.A. 1978. Factors effecting photosynthesis and its seasonal variation in the seagrass Cymodocea nodosa (Urica) Ashers., and Posidonia oceanica L. Delile in the Mediterranean. J.Exp.Mar.Biol.Ecol. 31:173-194.

Dring, M.J. 1982. The Biology of Marine Plants. Edward Arnold Publishers.

Fourqurean, J.W. and J.C. Zieman. 1991. Photosynthesis, respiration and whole plant carbon budget of the seagrass Thalassia testudinum. Mar.Ecol.Prog.Ser. 69:161-170.

Fonseca, M.S. J.S. Fisher, J.C. Zieman, G.W. Thayer. 1982 . Influence of the seagrass zostera marina on current flow. Estuarine, Coastal and Shelf Science. 15:351-64.

Goldsborough, W.J. and W.M. Kemp. 1988. Light responses of a submersed macrophyte: Implications for survival in turbid waters. Ecology 69:1775-86.

Hartman, R.T. and D.L. Brown. 1967. Changes in internal atmosphere of submersed vascular hydrophytes in relation to photosynthesis. Ecology 48:252-258.

Hines, M.E., S.L. Knollmeyer, and J.B. Tugel. 1989. Sulfate 
reduction and other sedimentary biogeochemistry in a northern New England salt marsh. Limnol. Oceanogr. 34(3):578-590.

Hootsman and Vermaat. 1991. Macrophytes, a key to undersatnding changes caused by eutrophication in shallow freshwater ecosystems.

Howarth, R.W. and A. Giblin. 1983. Sulfate reduction in the salt marshes at Sapelo Island, Georgia. 28(1):70-82.

Ingold, A. and D.C. Havill. 1984. The influence of sulphide on the distribution of higher plants in salt marshes. $72: 1043-1054$.

Joshi, M.M. and J.P. Hollis. 1977. Interaction of Beggiatoa and rice plant: detoxification of hydrogen sulfide in the rice rhizosphere. Science 195:179-80.

Kelly, M.G., N. Thyssen, and B. Moeslund. 1983. Light and the annual variation of oxygen- and carbon-based measurements of productivity in a macrophyte-dominated river. Limnol.Oceanogr. 28(3):503-515.

Kemp, W.M., M.R. Lewis, T.J. Jones. 1986. Comparison of methods for measuring production by the submersed macrophyte, Potomogeton perfoliatus. Limnol. Oceanogr. 31(6):1322-1334.

Kerr, B.A. and S. Strother. 1985. Effects of irradiance, temperature, and salinity on photosynthesis of Zostera muelleri. Aquatic Bot. 23:177-183.

Kikuchi, T. and J.M. Peres. 1977. Consumer ecology of the seagrass beds. In C.P. McRoy and C. Helfferich (eds), Seagrass Ecosystems A Scientific Perspective. Dekker, Basel, New York, pp.147-193.

King, G.M., M.J. Klug. 1982. Relation of soil water movement and sulfide concentration to spartina alterniflora production in a Georgia salt marsh. Science 218:61-63.

Kirk, J.T.O. 1983. Light and photosynthesis in aquatic ecosystems. Cambridge University Press.

Koch, M.S. and I.A. Mendelssohn. 1989. Sulphide as a soil phytotoxin: differential responses in two marsh species. Journal of Ecology 77:565-578.

Koch, M.S., I.A. Mendelssohn, K.L. McKee. 1990. Mechanism for the hydrogen sulfide-induced growth limitation in wetland macrophytes. Limnol. Oceanogr. 35(2):399-408.

Kuhn, W.A. 1992. The intertaction of light and sediment 
sulfide levels on eelgrass growth response. Master's Thesis, University of MD, MEES.

Libes, Maurice. 1986. Productivity-irradiance relationship of Posidonia oceanica and its epiphytes. Aquatic Bot. 26:285306 .

Lipkin, Y., S. Beer, E.P.H. Best, T. Kairesalo, and K. Salonen. 1986. Primary production of macrophytes: terminology, approaches and a comparison of methods. Aquatic Bot. 26:129-142.

Marsh, J.A., W.C. Dennison, and R.S. Alberte. 1986. Effects of temperature on photosynthesis and respiration in eelgrass. J.Exp.Mar.Biol.Ecol. 101:257-267.

Mazella, L. and R.S. Alberte. 1986. Light adaptation and the role of autotrophic epiphytes in primary production of the temperate seagrass, Zostera marina. J.Exp.Mar.Biol.Ecol. $100: 165-180$.

McRoy, C.P and C. McMillan. 1977. Production ecology and physiology of seagrasses. In: C.P. McRoy and C. Helfferich (eds.), Seagrass Ecosystems: A Scientific Prospective, Marcel Dekker, NY.

Mukai, H., K.Aioi, I. Koike, H. Iizumi, M. Ohtsu, and A. Hattori. 1979. Growth and organic production of eelgrass in temperate waters of the Pacific coast of Japan. I. Growth analysis in spring-summer. Aquatic Bot. 7:47-56.

Orth, R.J.,J.Nowak, A. Frisch, K.Kiley, and J. Whiting. 1987 and 1990. Distribution of Submersed Aquatic Vegetstion in the Chesapeake Bay and Tributaries and Chincoteague Bay.

Orth, R.J. and K.A. Moore. 1983. Seed germination and sedling growth of Zostera marina in the Chesapeake Bay. Aquatic Bot. $15: 117-131$.

Osmond, C.B., O. Bjorkamn, D.J. Andrum. 1980. Physiological Processes in Plant Ecology. Springer Verlag, New York.

Ott, J.A. 1980. Growth and production in Posidonia oceanica (L.) Delile. Mar. Ecol. S.Z.N.I., 1:47-64.

Penhale, Polly A. 1977. Macrophyte-epiphyte biomass and productivity in an eelgrass (Zostera marina L.) community. J.Exp.Mar.Biol.Ecol. 26:211-224.

Roberts, D.G. and J. Caperon. 1986. Lacunar gas discharge as a measure of photosynthesis in seagrasses. Mar. Ecol.Prog.Ser. $29: 23-27$. 
Roberts, D.G. and A.J. McComb. 1984. The structure and continuity of the lacunar system of the seagrass Halophila ovalis(R.Br.) Hook F. (Hydrocharitaceae). Aquatic Bot. $18: 377-388$.

Roberts, D.G. and D.J.W. Moriarty. 1987. Lacunal gas discharge as a measure of productivity in the seagrasses zostera capricorni, Cymodocea serrulata, and syringodium isoetifolium. Aquatic Bot. 28:143-160.

Salisbury, F.B. and C.W. Ross. 1985. Plant Physiology. Wadsworth Publishing Co.

Sand-Jensen, K., C. Prahl, H. Stokholm. 1982. Oxygen release from roots of submerged aquatic macrophytes. Oikos 38:349354 .

Sculthorpe, C.D. 1967. The biology of Aquatic Vascular Plants. Arnold.

Smith, R.D., W.C. Dennison, and R.S. Alberte. 1984. Role of seagrass photosynthesis in root aerobic processes. Plant Physiol. 74:1055-1058.

Smith, R.D., A.M. Pregnall, and R.S. Alberte. 1988. Effects of anaerobiosis on root metabolism of zostera marina (eelgrass): implications for survival in reducing sediments. Mar.Biol. 98:131-141.

Sorrell, B.K. and F.I. Dromgoole. 1986. Errors in measurements of aquatic macrophyte gas exchange due to oxygen storage in internal airspaces. Aquatic Bot. 24:103-114.

Spence, D.H.N. and J. Crystal. 1970. Photosynthesis and zonation of freshwater macrophytes. New Phytology 69:205-27.

Spence, D.H.N. 1975. Light and plant response in freshwater. In G.C. Evans, R. Bainbridge, O. Rackham (eds.), Light as an ecological factor. Blackwell, oxford, pp.93-133.

Strickland, J.D.H. 1958. Solar radiation penetrating the ocean. A review of requirements, data, and methods of measurement, with particular reference to photosynthetic productivity. J.Fish.Res.Board Canada, 15:453-493.

Thayer, G.W., D.A. Wolfe, and R.B.Williams. 1975. The impact of man on seagrass systems. American Scien. 63:288-296.

Wahbeh, Mohammad I. 1983. Productivity and respiration of three seagrass species from the Gulf of Aqaba (Jordan) and some related factors. 15:367-374. 
Ward, Larry, W.M. Kemp. 1984. The influence of waves and seagrass communities on suspended particles in an estuarine embayment. Marine Geology 59:85-103.

Wetzel, R.L. and P.A. Penhale. 1983. Production ecology of seagrass communities in the lower Chesapeake Bay. Mar Tech. Soc. J. 17:22-31.

Wiginton, J.R., C. McMillan. 1979. Chlorophyll composition under controlled light conditions as related to the distribution of seagrasses in Texas and the U.S. Virgin Islands. Aquatic Bot. 6:171-184.

Wilkon-Michalska, J. 1985. Structure and dynamics of the inland populations of Salicornia patula. Vegetation 61:14554 .

Williams, S.L. \& C.P. MCRoy. 1982. Seagrass productivity: the effect of light on carbon uptake. Aquatic Bot. 12:321-344.

Wood, E.J.F., W.E. Odum, and J.C. Zieman. 1969. Influence of seagrasses on the productivity of coastal lagoons. Lagunas Costeras, Simposio Mem. Simp. Intern. UNAM-UNES Co, Mexico, D.F.; Nov. 1967, pp.495-502.

Zieman, J.C. 1974. Methods for the study of the growth and production of turtle grass, Thalassia testudinum. Aquaculture $4: 139-143$.

Zieman, J.C. and R.G. Wetzel. 1980. Productivity in seagrass: Methods and Rates. In: R.C. Phillips and C.P. McRoy (eds.) Handboof of Seagrass Biology: an ecosystem perspective. Garland STPM Press, NY.

Zimmerman, R.C., R.D. Smith, R.S. Alberte. 1989. Thermal acclimation and whole plant carbon balance in Zostera marina (eelgrass). J.Exp.Mar.Biol.Ecol. 130:93-109. 


\section{VITA}

\section{Iill Lynn Goodman}

Born in Snow Hill, MD on January 31, 1968. Graduated Snow Hill High School in 1986. Graduated cum laude with a B.S. in Biology from Salisbury State University in June 1990. Entered School of Marine Science, College of William and Mary August 1990 . 